\title{
Current Cost and Performance Requirements for Residential Cool Storage Systems
}

\author{
D. R. Brown \\ G. E. Spanner
}

August 1988

Prepared for the U.S. Department of Energy under Contract DE-AC06-76RLO 1830

Pacific Northwest Laboratory

Operated for the U.S. Department of Energy by Battelle Memorial Institute 


\section{DISCLAIMER}

This report was prepared as an account of work sponsored by an agency of the United States Government. Neither the United States Government nor any agency thereof, nor Battelle Memorial Institute, nor any or their employees, makes any warranty, expressed or implied, or assumes any legal liability or responsibility for the accuracy, completeness, or usefulness of any information, apparatus, product, or process disclosed, or represents that its use would not infringe privately owned rights. Reference herein to any specific commercial product, process, or service by trade name, trademark, manufacturer, or otherwise does not necessarily constitute or imply its endorsement, recommendation, or favoring by the United States Government or any agency thereof, or Battelle Memorial Institute. The views and opinions of authors expressed herein do not necessarily state or reflect those of the United States Government or any agency thereof, or Battelle Memorial Institute.

\section{PACIFIC NORTHWEST LABORATORY operated by \\ BATTELLE MEMORIAL INSTITUTE for the UNITED STATES DEPARTMENT OF ENERGY under Contract DE-AC06-76RLO 1830}

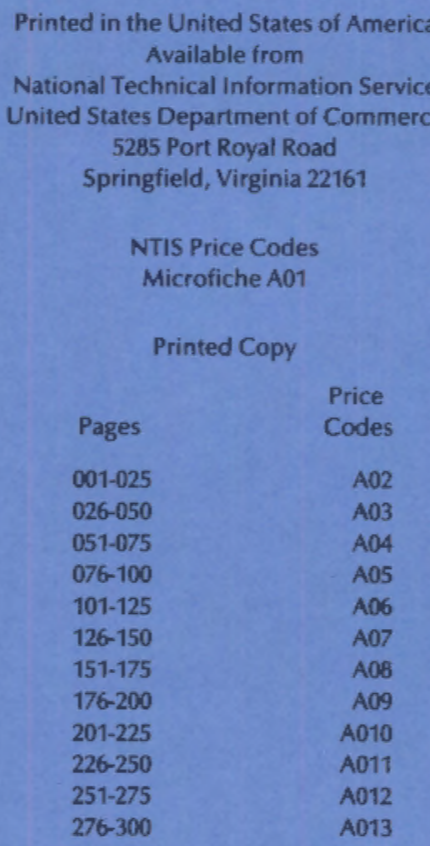


CURRENT COST AND PERFORMANCE REQUIREMENTS

FOR RESIDENTIAL COOL STORAGE SYSTEMS

D. R. Brown

G. E. Spanner

August 1988

Prepared for

the U.S. Department of Energy

under Contract DE-AC06-76RLO 1830

Pacific Northwest Laboratory

Richland, Washington 99352 



\section{PREFACE}

This study defines the current cost and performance requirements for residential cool storage technologies based on the characteristics of conventional air conditioning equipment and residential time-of-day (TOD) rate structures existing during the 1986-1987 time frame. A companion document, Estimating the Market Penetration of Residential Cool Storage Technology Using Economic Cost Modeling, has also been prepared.

Currently, rate structures are changing rapidly. Given the volatility of rate structures, the establishment of cost goals is challenging. The goals presented in this study are based on the utility rate structure as of 1986 .

This study serves to define residential cool storage cost and performance requirements in the current economic environment as well as the many issues affecting the requirements for residential cool storage systems both now and in the future. The same methodology can be employed to establish long-run goals once future rate structures are adequately defined. 

SUMMARY

Cool storage systems have the potential to reduce the overall cost of cooling for residential customers by shifting all or part of the electric load occurring during peak demand periods to off-peak periods, thus lowering the total electric bill. The objective of this study was to develop current system initial capital cost and annual performance requirements for cool storage technologies in residential applications. The requirements were developed by considering the cost and performance of currently available residential cooling equipment and the economic opportunity for employing storage. The resulting cost and performance requirements, if achieved, would make the new technologies economically competitive with the conventional technology, assuming that both provide the same or similar service. The following four steps outline the general procedure for developing the requirements:

1. Identify the service to be provided by the new technology.

2. Identify the conventional means of providing the same or similar service.

3. Characterize the cost, performance, and economic figure-of-merit for the conventional means of providing the service.

4. Solve for the combinations of cost and performance for the new technology that match the conventional technology's figure-of-merit.

Initial capital cost and annual coefficient-of-performance (COP) requirements were developed for one new construction and two retrofit scenarios for nine combinations of site and building type. Two retrofit scenarios were necessary to distinguish between thermal energy storage (TES)-augmented systems that would fully replace the conventional equipment and add-on TES equipment. St. Louis, Missouri; Pittsburgh, Pennsylvania; and Hartford, Connecticut were selected for analys is because they represented the 90th, 50th, and 10th percentile sites, respectively, when prospective sites were ranked by the combination of cooling-degree-days and peak/off-peak electric rate differential. The three building types included were ranch, two-story, and townhouse residences. 
A TES-augmented system in the new construction scenario with the same annual COP as the reference system would be worth an additional $\$ 999$ above the initial cost of the reference systent for a ranch house in St. Louis. Similarly, a TES-augmented system would be worth an additional $\$ 860$ and $\$ 624$, respectively, for two-story and townhouse residences in St. Louis. Alternatively, a TES-augmented system with the same initial cost as the reference system would need to have an annual COP roughly half that of the reference system for any of the three building types in St. Louis.

Conditions are less attractive in Hartford and Pittsburgh. Here the additional worth of a TES-augmented system with a COP equal to its reference system ranges from $\$ 62$ for the two-story house in Hartford to $\$ 246$ for the ranch house in Pittsburgh. St. Louis is more attractive because of its higher annual cooling load and large electric rate differential for moving to offpeak. Pittsburgh is more attractive for TES than Hartford because of its higier electric rate differential, even though it has the lowest annual cooling load. For TES-augmented systems with the same initial cost as the reference system, the annual COP need only be roughly $50 \%$ of the reference system in Pittsburgh. much like the case in St. Louis. In Hartford, where the benefit per kwh of shifting the electric load off-peak is lower than for either St. Louis or Pittsburgh, the annual COP required for a TES-augmented systen with the same initial cost as the reference system must be greater than $80 \%$ of the cop for the reference systen.

The prospects for TES in the retrofit/replacement system scenario are extremely limited. For each of the nine pairs of cities and bujldings, the TES-augmented replacement system would have to either be less expensive than its corresponding conventional unit while achieving the same annual COP or achieve a higher annual cop for the same cost.

The general trends and prospects for TES in the retrofit/add-on system scenario are similar to those found for the new construction scenario and are caused by the same factors. For example, a TES add-on resulting in the same annual COP as the reference system would be worth an additional $\$ 1105, \$ 951$, and $\$ 689$, respectively, for ranch, two-story, and townhouse residences in $S t$. 
Louis. Alternatively, if the TES add-on was free, the resultant system would need to have an annual COP roughly half that of the reference system for any of the three building types in St. Louis.

Sensitivity analyses were conducted for alternative storage sizing, reference (conventional) system electric rate structure, and financing rate assumptions. As a general rule, the chill-generator and storage unit were assumed to be sized to allow all of the peak cooling load to be moved offpeak. Assuming the chill-generator and storage unit would be sized so that the chill-generator ran continuously (24 hours per day) on the peak cooling day of the year reduced the initial capital cost requirements by $15 \%$ or less for a given level of annual COP. Basing the reference (conventional) system's annual electric bill for cooling on the optional time-of-day (TOD) rate (which yielded a higher annual electric bill for cooling than the flat rate) increased the initial capital cost requirements by up to $30 \%$ for a given level of annual COP. Finally, using 5.9\% rather than $10 \%$ as the financing rate increased the initial capital cost requirements by up to $15 \%$ for a given level of annual COP.

The prospects for residential cool storage vary dramatically, depending on the meteorology and utility rate structure at a particular site. Both the cooling load (for the same building size) and electric rates vary by more than an order of magnitude across the U.S. Selection of any specific combination of initial capital cost and annual COP as the singular requirement for residential cool storage must consider a specific target share of the residential market.

The prospects for residential cool storage also depend on the perspective of the homeowner and the nature of the TES-augmented system. Residential cool storage systems are much more likely to be economically attractive in new construction applications or as add-on technology in retrofit applications. Full replacement systems in retrofit applications are unlikely to be economically feasible.

The current cost and performance requirements identified in this study would be very difficult to achieve. A previous study conducted for the Electric Power Research Institute (Asbury, Giese, and Looney 1986) concluded that a 
TES-augmented cooling system could probably be installed for a $\$ 2000$ premium above the cost of a conventional cooling system, but noted that very few utility rate structures provide the residential class with a sufficient level of financial incentive for shifting air conditioning demand to off-peak. The cost and performance requirements identified in this study confirm this dilemma. Based on the current characteristics of residential air conditioning equipment and rate structures, the allowable cost premium in St. Louis (the most attractive of the three sites evaluated in this study) was estimated to be only $\$ 1000$.

However, during the time frame this study was conducted (1987-1988), the availability of TOD rates for the residential class was rapidly increasing. of particular importance, many Southern utilities (where cool storage technologies are expected to have the greatest potential) did not have TOD rates for the residential class at the beginning of the study, but were implementing this type of rate structure as the analytical portion of this study came to a close. The increased availability of TOD rates or other incentives for employing residential cool storage within Southern utilities would significantly change the results of this study. Follow-on efforts should be directed toward tracking the changes in residential rate structures and identifying futureoriented cost and performance requirements when the long-run characteristics of the structure for the residential rate class is more certain. 


\section{ACKNOWLEDGMENTS}

This work, supported by the U.S. Department of Energy (DOE), is part of the Underground Energy Storage Program at the Pacific Northwest Laboratory (PNL). PNL is operated by Battelle Memorial Institute for DOE under Contract DE-AC06-76RLO 1830.

Several staff at PNL have assisted the authors in the preparation of this document. K. K. Humphreys provided input on the initial capital cost and maintenance cost of conventional air conditioning equipment. D. L. Stiles helped prepare the rankings of prospective sites. D. B. Crawley and K. R. Taylor operated the DOE-2 model that produced cooling load, electric load, and cost estimates for electricity. Finaliy, S. J. Arey was responsible for typing and publication preparation. 


\section{.}




\section{CONTENTS}

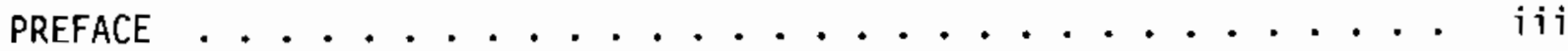

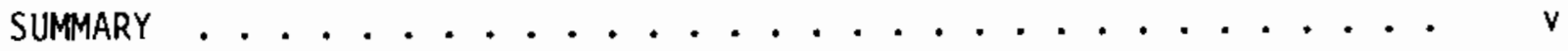

ACKNOWLEDGEMENTS ......................... ix

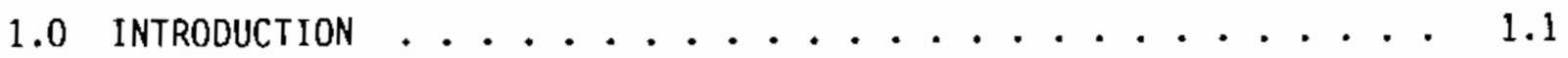

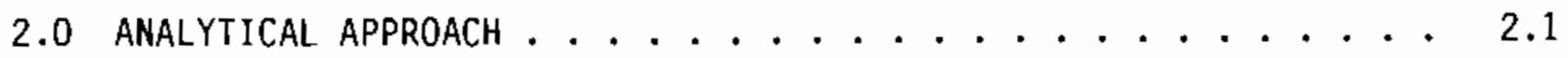

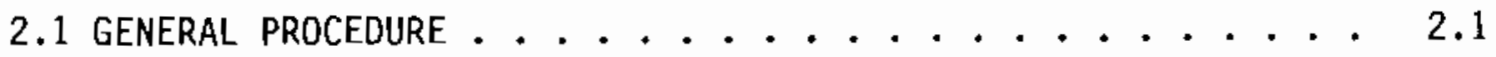

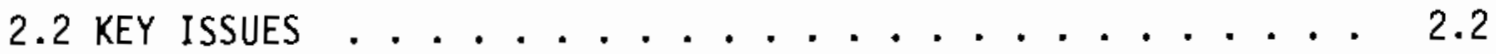

2.2.1 Reference Cooling System . . . . . . . 2.2

2.2.2 Site Selection ............... 2.2

2.2 .3 Building Cooling Load ............ 2.4

2.2 .4 Storage System Size .......... 2.5

2.2.5 Cost and Performance Requirement Calculations . . 2.6

2.2.6 Unique Perspectives and Applications ...... 2.7

3.0 SITE SELECTION . . . . . . . . . . . . 3.1

4.0 BUILDING COOLING AND ELECTRIC LOADS ............ 4.1

$4.1 \mathrm{DOE}-2 \ldots \ldots \ldots \ldots . \ldots . \ldots . \ldots . . \ldots 4$

4.2 RESIDENTIAL BUILDINGS MODELED . . . . . . . . . . . 4.2

4.3 COOLING SYSTEM PERfORMANCE .................... 4.3

4.4 COOLING SYSTEM SIZING . . . . . . . . . . 4.4

4.5 COOLING AND ELECTRIC LOAD RESULTS . . . . . . . . . 4.4

5.0 SYSTEM LEVEL REQUIREMENTS . . . . . . . . . . . . . 5.1

5.1 RefERENCE SYSTEM COSTS .......................... 5.1

5.2 Life-CYCle COST CalCUlations . . . . . . . . . . . 5.2 
6.0 TES-AUGMENTED SYSTEM COST AND PERFORMANCE REQUIREMENTS $\ldots . . . \quad$. 6.1

6.1 ANALYTICAL APPROACH .................. 6.1

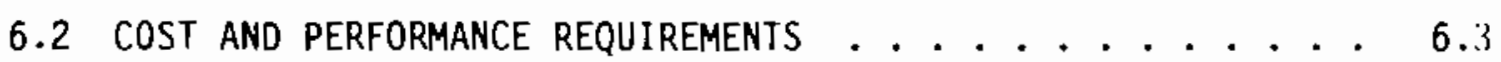

6.3 SENSITIVITY CASES . . . . . . . . . . . . . 6.21

6.3.1 Alternative Storage Sizing .......... . 6.13

6.3.2 Alternative Rate Structure . . . . . . . . 6.16

6.3.3 Alternative Financing Rate ........... 6. 6.19

7.0 CONCLUSIONS . . . . . . . . . . . . . . . . . . . . . 7.1

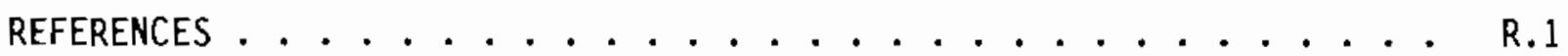




\section{FIGURES}

2.1 The Boundary Between Acceptable and Unacceptable Combinations of Initial Capital Cost and Annual COP . . . . . . . . 2.8

6.1 Initial Capital Cost and Annual Cop Requirements for a TES-Augmented System in the New Construction Scenario . . . . 6.5

6.2 Initial Capital Cost and Annual CoP Requirements for a TES-Augmented System in the Retrofit/Add-on System Scenario . . 6.10

6.3 Storage-Sizing Sensitivity and Base-Case Figures . . . . . . . 6.14

6.4 Rate Structure Sensitivity and Base-Case Figures . . . . . . . 6.17

6.5 Financing Rate Sensitivity and Base-Case Figures . . . . . . 6.20 



\section{$\underline{\text { TABLES }}$}

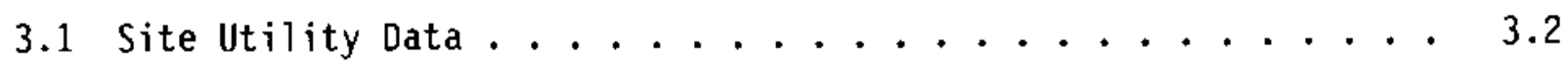

3.2 Site Meteorological Data ............. 3.3

3.3 0verall Site Ranking ................. 3.4

3.4 Characteristics of Sites Selected ........... 3.5

4.1 Annual Cooling and Electric Loads . . . . . . . . . . 4.5

4.2 Annual Electric Bills for Cooling . . . . . . . . . . 4.5

4.3 Hourly Cooling Loads on the Peak Cooling Day for the St. Louis Ranch House ................ . 4.8

4.4 Hourly Cooling Loads on the Peak Cooling Day for the Pittsburgh Ranch House ................ 4.9

4.5 Hourly Cooling Loads on the Peak Cooling Day for the Hartford Ranch House ................. 4.10

5.1 Reference Air Conditioning System Capital and Maintenance Costs .................. 5.2

5.2 Economic Assumptions ............... 5.3

5.3 Life-Cycle Cost Results . . . . . . . . . . . . 5.3

5.4 Life-Cycle Cost Components for the New Construction Scenario . 5.4

5.5 Life-Cycle Cost Components for the Retrofit Scenario . . . . 5.4

6.1 New Construction Scenario Cost and Performance Requirements . . 6.4

6.2 Retrofit/Replacement System Scenario cost and Performance Requirements . . . . . . . . . 6.7

6.3 Retrofit/Add-0n System Scenario Cost and Performance Requirements .............. . . 6.9

6.4 Retrofit/Add-0n System Scenario Cost and Performance Requirements: Alternative Cost Units .......... 6.12 
6.5 Alternative Storage Sizing Results, St. Louis Ranch House ................... 6.15

6.6 Alternative Rate Structure Results, St. Louis Ranch

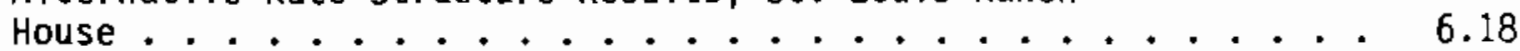

6.7 Alternative Financing Rate Results, St. Louis Ranch House ....................... 6.21 
CURRENT COST AND PERFORMANCE REQUIREMENTS FOR RESIDENTIAL COOL STORAGE SYSTEMS

\subsection{INTRODUCTION}

Cool storage systems have the potential to reduce the overall cost of cooling for residential customers by shifting all or part of the electric load occurring during peak demand periods to off-peak periods, thus lowering the total electric bill. The potential energy cost savings are substantial. In some locales the difference between the peak and off-peak energy charges are greater than $\$ 0.100 / \mathrm{kWh}$. This savings potential is the primary driving force for developing cool storage systems for residential applications.

The overall objective of this study, conducted at Pacific Northwest Laboratory $(\mathrm{a})$, was to establish current system initial capital cost and annual performance requirements for cool storage technologies in residential applications. The requirements are intended to be used by developers and technology evaluators as a benchmark for comparison with the actual cost and performance characteristics of prospective cool storage systems. The requirements represent combinations of system cost and performance that, if achieved, would make the cool storage system economically competitive with a conventional air conditioning (AC) system. By comparing the actual or projected characteristics of cool storage systems with the requirements established in this study, technology developers, evaluators, and planners can obtain a better understanding of the potential for a prospective cool storage system and make more informed decisions about research and development directions.

Section 2.0 describes the general analytical approach. Sections 3.0 and 4.0 describe the site selection process, and building cooling and electric load modeling, respectively. System level (life-cycle cost) requirements are presented in Section 5.0. Section 6.0 presents the cost and performance requirements for the thermal energy storage (TES)-augmented systems. Finally, the study's conclusions are discussed in Section 7.0 .

(a) Operated for the U.S. Department of Energy by Battelle Memorial Institute. 



\subsection{ANALYTICAL APPROACH}

The objective of this study was to establish current cost and performance requirements for cool storage technologies in residential applications. Establishing these requirements would serve the following purposes.

- The requirements identify a set of cost and performance characteristics that would make cool storage an economically attractive option for different segments of the residential cooling market.

- The requirements provide a benchmark for measuring the research and development progress of concepts being developed.

- Development of the requirements focuses attention on the interaction of multiple factors affecting the potential attractiveness of cool storage.

\subsection{GENERAL PROCEDURE}

Cost and performance requirements for residential cool storage were developed by considering the cost and performance of currently available residential cooling equipment and the economic opportunity for employing storage. The resulting market-based requirements, if achieved, would make the new technologies economically competitive with the conventional technology or operating procedure, assuming that both provide the same or similar service. The following four steps outline the general procedure for developing market-based requirements:

1. Identify the service to be provided by the new technology.

2. Identify the conventional means of providing the same or similar service.

3. Characterize the cost, performance, and economic figure-of-merit for the conventional means of providing the service. This establishes the overall system level requirement.

4. Solve for the combinations of cost and performance for the new technology that match the conventional technology's figure-of-merit. 


\subsection{KEY ISSUES}

The generalized framework described above requires the resolution of several issues to become a working analytical approach. Key issues impacting the direction of this study are discussed in the sections that follow.

\subsubsection{Reference Cooling System}

The following issues were considered in selecting the reference (conven. tional) residential cooling system:

- What criteria should be used to select the reference system(s)?

- Is more than one reference system necessary or desirable?

- Should the focus be on new construction or retrofit?

- How should combination heating and cooling equipment be treated?

The principal selection criterion was the market share of currently available residential cooling technology. The predominate technology, which was selected as the reference technology, was found to be a central cooling system consisting of an evaporator coil mounted in the indoor air circulating syster and a remote air-cooled condensing unit. The condensing unit contains an electric motor-driven compressor, condenser, condenser fan and fan motor, and electric controls. The system working fluid is freon. This type of system was found to be the most common for homes built in the past and for new construction. Average system efficiencies have gradually improved over the years, but the basic system has remained relatively unchanged. Heat pump systens capable of providing heat or chill also represent a significant (although smaller) fraction of the market, but because they employ essentially the same equipment for supplying chill at approximately the same efficiency as the standard air conditioning ( $A C$ ) system described above, they were not considered separately. Requirements developed based on competition with the standard $A C$ systems will also be generally applicable to competition with (air-to-air) heat pumps.

\subsubsection{Site Selection}

The number of cooling-degree-days (a general indicator of expected relative residential cooling loads) and utility rate schedules each vary across the U.S. by an order of magnitude or more. The variability of these factors and 
their impact on the development of the requirements make site selection an extremely important, if not the most important, factor to consider. The following specific issues were considered in selecting the sites:

- Should the climate and rate structure characteristics be associated with specific or generic sites?

- Should the rate structure characteristics be based on currently published rate tables or the utilities' avoided costs?

- Should sites be selected or site characteristics be developed to represent the most attractive (for chill storage) situations, median or typical situations, or less attractive situations?

- What characteristics of climate and utility rate structures make chill storage attractive?

A utility's avoided cost is its marginal cost of production, whereas the consumer's electric rate tends to represent the average cost of production plus transmission and distribution costs. The exact relationship between the utility's cost and the consumer's rate often involves a complex set of rules established by the local utility commission. The use of time-of-day (TOD) rates, seasonal rates, and demand charges are attempts to more precisely allocate a utility's cost of supplying power to its customers. However, these rates and charges do not exactly match a utility's supply cost at any given time. In fact, no matter how finely a utility segments its rate structure, the allowable charges in any one period will nomally reflect the average cost of power for that period rather than the utility's marginal or avoided cost. Thus, the customer's rate structure does not usually reflect the total value to the utility of reducing the consumption of electricity during a peak demand period. Therefore, it may be in the best interest of the utility to offer additional incentives to consumers for certain load management practices. Incentives are common in the commercial sector, but few, if any, utilities currently offer special incentives (such as rebates for TES systems) to residential customers, perhaps because the cost of handling the additional paperwork outweighs the potential benefit to the utility in the residential sector. 
Currently published rate structures were chosen as the basis for establishing the cost and performance requirements because they represent the actual current costs that a residential customer would use in making his or her decision on whether to purchase a TES system. Future movement by utilities toward residential rate structures and incentives that more closely account for their cost of production was judged to be too speculative to consider in this study. Approximately one-third of the investor-owned utilities (50) offer TOD rates for residential customers (as of 1986). A handful of these also impose demand charges for this type of service. In general, the following conditions make cool storage more attractive:

- a higher differential between peak and off-peak energy rates - This differential provides the primary economic driving force for considering chill storage when demand charges do not apply.

- a higher ratio of peak to off-peak energy rates - This ratio defines the minimum acceptable storage performance (for a storage system that costs nothing to build and maintain).

- a larger number of annual cooling-degree days - Residential cooling loads are strongly correlated with the number of cooling-degreedays. In general, the greater the cooling load, the greater the potential benefit of incorporating cool storage.

The approach used was to select three sites representing relatively attractive (but not the best), typical, and relatively unattractive (but not the worst) combinations of the above variables. The intent was to identify the sensitivity of the requirements to site selection and develop information that would allow the estimating of potential market penetration as a function of storage cost and perfomance. Additional details regarding the site selection procedure and the meteorological and utility characteristics of the sites selected are presented in Section 3.0 .

\subsubsection{Building Cooling Load}

One of the critical issues facing the process of developing the requirements was the approach for calculating building cooling loads. The estimation 
of a building's cooling load is a complex analytical calculation involving the following key building-specific factors, among many others:

- building floor area and layout

- type, quantity, and location of insulation

- internal heating loads

- ventilation practices

- target indoor temperature and humidity.

An additional complication is the desire to predict the load on an hourly basis. Hourly load estimates are required to segregate peak loads from offpeak loads. Relatively simple methods that produce annual, monthly, or even daily load estimates are not adequate. The DOE-2 model developed by the Lawrence Berkeley and Los Alamos laboratories has the capability to simulate hourly performance. In addition, the characteristics of five generic building types, representing more than $90 \%$ of all new residences built in the United States, have been specified for use with the model. The DOE-2 model was used to estimate the hour-by-hour cooling load over 1 year for three residential building types at each of three sites, thus creating a matrix of nine site and building type combinations.

\subsubsection{Storage System Size}

Selecting the system storage size is a key design factor that directly impacts the peak load that can be moved off-peak and the size of the chillgenerating equipment. Two sizing options represent the most commonly chosen design conditions:

- Size storage and chill-generating equipment to move all of the peak cooling load off-peak on the day with the largest peak cooling load of the year (load-shifting strategy).

- Size storage and chill-generating equipment to require constant 24-hour operation of the chill-generating equipment on the day with the largest peak cooling load of the year (load-leveling strategy).

The first option moves the entire annual load occurring during peak hours to off-peak hours, resulting in the maximum potential energy cost savings. However, peak periods may last 12 hours, resulting in a larger chill-generating 
device than the conventional system requires, which would reduce the energy cost savings. The second storage-sizing approach would typically result in lower potential energy cost savings, but would benefit the user by requiring a smaller chill-generating device. The optimal size for storage will depend on the site-specific load and electricity rate structure, as well as on the storage system cost and performance. Because the site-specific factors vary significantly and the analytical procedure solves for the storage system cost and performance, the optimal storage size and chill-generating capacity could not be determined in advance. The first option was selected as the reference case based on recommendations in Asbury, Giese, and Looney (1986), and the second option was considered in a sensitivity analysis.

\subsubsection{Cost and Performance Requirement Calculations}

At issue here are assumptions regarding the charging and discharging of storage, the displacement of peak energy demands, and the characterization of system performance. Specifically, the following issues are of concern.

- How much of the peak cooling demand is actually shifted to off-peak hours during operation?

- How much of the storage is charged each day?

- At what level of detail should system performance be characterized?

It was presumed that adequate chill would be available each day from the storage unit to displace the entire peak cooling demand for storage units sized via the reference method described above. Recharging of storage is presumed to occur after the peak period ends each day. From a practical operating standpoint, this implies that the storage unit would be fully charged at the start of each day or that a more sophisticated load projection technique would be employed to ensure that an adequate (usually less than fully charged) supply of chill is available to meet the following day's peak-period load. The resultant standby losses (from being partially or fully charged 24 hours a day) are a part of the overall system-level performance that also includes charging and discharging losses (e.g., transport losses) and any other operating inefficiencies. The procedure for developing the requirements solves for this 
single overall performance figure-of-merit and leaves the individual components to the discretion of the storage technology developer.

As indicated above, the requirements were established by solving for combinations of initial capital cost and annual performance for the storageaugmented cooling system that match the conventional technology's life-cycle cost of cooling. The general calculational procedure was as follows.

1. Assume that adequate chill storage capacity will be available to move all of the peak electric demand to off-peak. (Note that not all of the peak cooling demand will be met by either the conventional or TES-augmented systems, per standard design practices.)

2. Make an initial assumption for the TES-augmented system annual roundtrip efficiency (annual COP).

3. Calculate the annual consumption and cost of electricity for the TES-augmented system.

4. Solve for the TES-augmented system initial capital cost (and implied annual operation and maintenance cost) that results in the same system-level cost of delivered chill as the conventional system.

5. Repeat steps 3 and 4 for other round-trip efficiency assumptions.

The result of this procedure is a curve (see figure 2.1) defining the boundary between acceptable and unacceptable combinations of initial capital cost and annual COP.

\subsubsection{Unique Perspectives and Applications}

Different decision-making perspectives of homeowners and the nature of the prospective cool-storage systems require separate cost and performance requirements. The two key issues considered can be summarized as follows:

- Is the prospective cool storage system being considered from the perspective of new construction or as a retrofit?

- Will the prospective cool storage system be an accessory to or completely replace a conventional air conditioning system? 


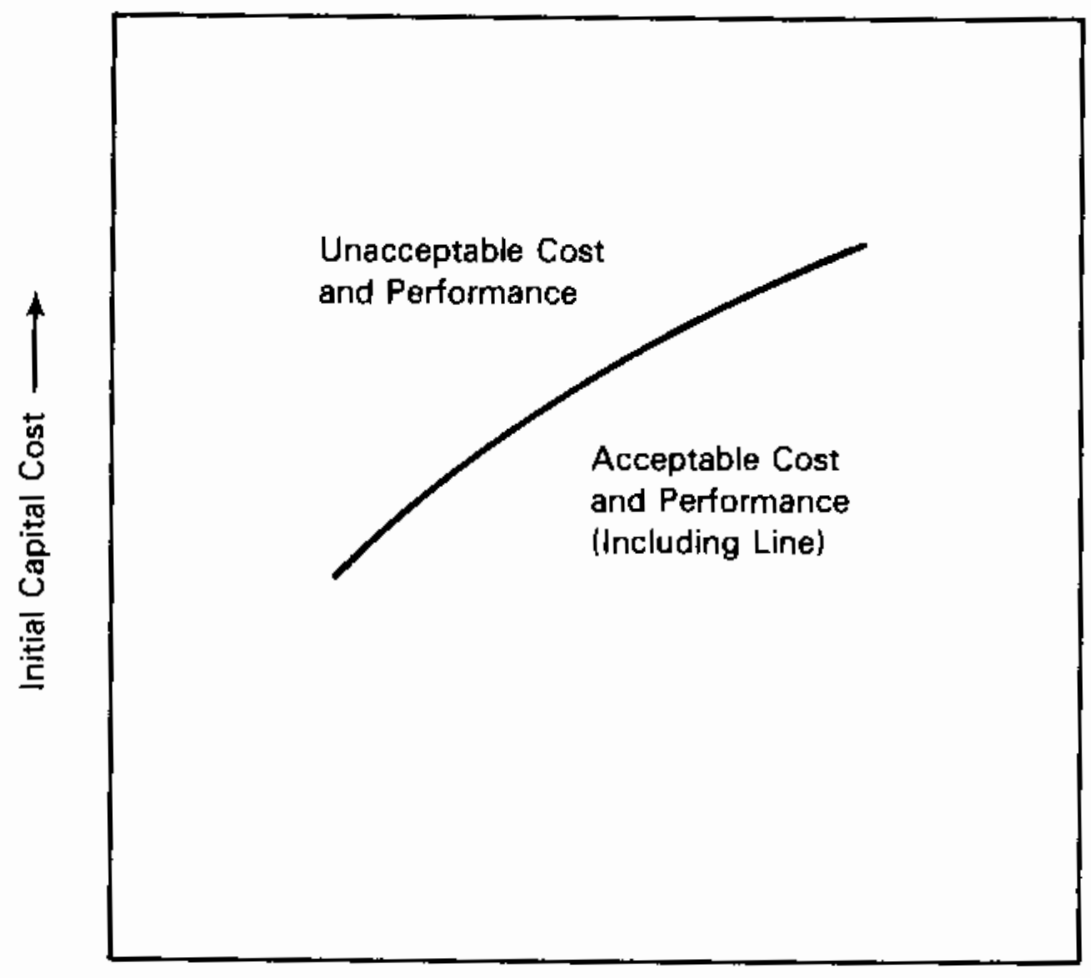

Annual COP

FIGURE 2.1. The Boundary Between Acceptable and Unacceptable Combinations of Initial Capital Cost and Annual COP

The most common perception of a cool storage system is a storage unit with charging and discharging (e.g., transport) accessories augmenting conventional air conditioning equipment. However, an integrated chill-generating and storing unit (a single piece of equipment) that completely replaces the conventional system is possible. Thus, developing the requirements is focus sed at the system level. Even if the cool storage technology is an add-on to a conventional system, restrictive assumptions regarding the nature of the tec:1nology would have to be made to develop requirements for the storage unit itself. Thus, the focus in this study is on system-level requirements.

The reference cost of cooling in a retrofit situation will be less than in a new construction situation because the homeowner would have to pay only for the continued operation and maintenance of an air conditioning system rather than the purchase, operation, and maintenance of a new air conditioner. 
Thus, separate requirements were developed for new construction and retrofit situations. The retrofit situation was further subdivided to allow for the case where cool storage is an add-on to a conventional system and for the case where a cool-storage system completely replaces the conventional system. 



\subsection{SITE SELECTION}

The importance of the cooling load and utility rate structure in determining cost and performance requirements for residential cool storage systems was discussed in Section 2.2.2. Utilities listed in the Electric Rate Book (CSA Energy Consultants 1986) who offered TOD rates for residential customers were identified as candidates for residential cool storage. Representative cities in or near the utility districts were identified to establish the meteorological basis. Prospective cities were limited to those with the Typical Meteorological Year (TMY) data required for the building cooling load calculations.

The prospective sites for residential cool storage were ranked by their two primary characteristics (cooling load and peak/off-peak electric rate differential) that make cool storage attractive. Sites close to the 90th, 50th, and 10th percentiles were selected for developing the requirements. The reason for this approach was to select multiple sites representing a broad range of rate structures and meteorological characteristics within the population of candidate sites. The approach specifically avoids selecting the best or worst sites, which would lead to a set of less meaningful requirements.

Without previous knowledge of their relative importance, the number of cooling-degree-days and the peak/off-peak electric rate differential were assigned an equal weight in developing the rankings. Raw data for coolingdegree-days and the peak/off-peak electric rate differential were normalized by dividing the actual value for a specific site by the average value for all of the sites. The normalized figures for cooling-degree-days and peak/offpeak electric rate differential were then added to yield a single figure-ofmerit for ranking. Tables 3.1, 3.2, and 3.3 show the utility data, meteorological data, and subsequent overall ranking for the candidate sites. St. Louis, Pittsburgh, and Hartford were selected as representative of 90th, 50th, and 10th percentile sites, respectively. Utility rate structure and meteorological data are summarized in Table 3.4 for these three cities. 
IABLE 3.1. Site Utility Data

\begin{tabular}{|c|c|c|c|c|}
\hline City & $\begin{array}{l}\text { Peak Rate, } \\
\text { cents } / \text { kwh }\end{array}$ & $\begin{array}{l}\text { Off-Peak Rate, } \\
\text { cents/kwh }\end{array}$ & $\begin{array}{l}\text { Differential, } \\
\text { cents/kwh }\end{array}$ & $\begin{array}{c}\text { Normalized } \\
\text { Differential }\end{array}$ \\
\hline 0klahoma City & 16.96 & 3.84 & 13.13 & 2.131 \\
\hline Morristown & 14,00 & 3.26 & 10.74 & 1.744 \\
\hline Madison & 13.83 & 3.10 & 10.73 & 1.742 \\
\hline Milwaukee & 13.05 & 2.75 & 10.30 & 1.672 \\
\hline Green Bay & 13.20 & 2.96 & 10.24 & 1.662 \\
\hline St. Louis & 14.77 & 4.59 & 10.18 & 1.652 \\
\hline Oes Moines & 13.97 & 4.08 & 9.89 & 1.605 \\
\hline Providence & 11.13 & 1.41 & 9.72 & 1.577 \\
\hline Albuquerque & 15.08 & 6.05 & 9.03 & 1.465 \\
\hline Tampa & 10.48 & 1.49 & 8.99 & 1.459 \\
\hline Green Bay & 12.01 & 3.15 & 8.86 & 1.438 \\
\hline Littie Rock & 13.26 & 4.42 & 8.84 & 1.435 \\
\hline Еан Claire & 11.34 & 2.63 & 8.71 & 1.414 \\
\hline Newark & 16.23 & 7.81 & 8.42 & 1.367 \\
\hline Bismark & 11.00 & 2.63 & 8.37 & 1.359 \\
\hline Cincinnati & 9.86 & 2.00 & 7.86 & 1.276 \\
\hline Fort Hayne & 9.77 & 2.43 & 7.34 & 1.192 \\
\hline Pocatelio & 10.80 & 3.78 & 7.02 & 1.139 \\
\hline Port Arthur & 8.50 & 1.59 & 6.91 & 1.122 \\
\hline Grand Rapids & 11.00 & 4.20 & 6.80 & 1.104 \\
\hline Sioux Falls & 9.93 & 3.16 & 6.77 & 1.099 \\
\hline Pittsburgh & 10.45 & 4.05 & 6.40 & 1.039 \\
\hline Allentown & 10.71 & 4.39 & 6.32 & 1.026 \\
\hline Minneapolis & 9.65 & 3.69 & 5.96 & 0.967 \\
\hline Minot & 8.56 & 2.79 & 5.77 & 0.937 \\
\hline Portland & 9.98 & 4.32 & 5.67 & 0.920 \\
\hline Miles City & 11.31 & 5.65 & 5.65 & 0.918 \\
\hline Binghamton & 9.09 & 3.49 & 5.60 & 0.909 \\
\hline Concord & 10.88 & 5.37 & 5.51 & 0.894 \\
\hline Boston & 6.78 & 1.38 & 5.40 & 0.877 \\
\hline South Bend & 7.72 & 2.90 & 4.82 & 0.782 \\
\hline Binghamton & 8.50 & 3.77 & 4.73 & 0.768 \\
\hline Moline & 7.17 & 2.56 & 4.61 & 0.748 \\
\hline Pittsburgh & 8.04 & 3.57 & 4.47 & 0.726 \\
\hline Syracuse & 8.40 & 4.04 & 4.36 & 0.708 \\
\hline Boston & 5.88 & 1.58 & 4.30 & 0.698 \\
\hline New York & 11.83 & 7.70 & 4.13 & 0.670 \\
\hline Knoxville & 6.75 & 2.77 & 3.98 & 0.645 \\
\hline Hartford & 10.92 & 7.42 & 3.50 & 0.568 \\
\hline Roanoke & 5.10 & 1.79 & 3.30 & 0.536 \\
\hline Moline & 7.08 & 4.37 & 2.71 & 0.440 \\
\hline Charleston & 5.69 & 3.30 & 2.39 & 0.387 \\
\hline Pittsburgh & 6.01 & 4.18 & 1.83 & 0.297 \\
\hline Moline & 5.78 & 4.10 & 1.68 & 0.273 \\
\hline Moline & 5.35 & 3.78 & 1.57 & 0.255 \\
\hline Cleveland & 6.17 & 4.62 & 1.55 & 0.752 \\
\hline Columbia & 4.10 & 2.90 & 1.21 & 0.196 \\
\hline Raleigh & $4.0 ?$ & 2.88 & 1.14 & 0.18 .5 \\
\hline Akron & 1.50 & 1.50 & 0.00 & 0.000 \\
\hline Denver & 2.60 & 2.60 & 0.00 & 0.000 \\
\hline
\end{tabular}


TABLE 3.2. Site Meteorological Data

\begin{tabular}{|c|c|c|}
\hline City & Cooling-Degree-Days (CDD) & Normalized CDD \\
\hline Tampa & 3366 & 3.732 \\
\hline Port Arthur & 2797 & 3.101 \\
\hline Columbia & 2086 & 2.313 \\
\hline Charleston & 2077 & 2.303 \\
\hline Little Rock & 1924 & 2.133 \\
\hline Oklahoma City & 1876 & 2.080 \\
\hline Knoxville & 1568 & 1.739 \\
\hline St. Louis & 1474 & 1.634 \\
\hline Raleigh & 1393 & 1.545 \\
\hline Albuquerque & 1316 & 1.459 \\
\hline Cincinnati & 1080 & 1.198 \\
\hline New York & 1067 & 1.183 \\
\hline Roanoke & 1030 & 1.142 \\
\hline Newark & 1022 & 1.133 \\
\hline Des Moines & 927 & 1.028 \\
\hline Moline & 893 & 0.990 \\
\hline Allentown & 770 & 0.854 \\
\hline Miles City & $75 i$ & 0.833 \\
\hline Fort Wayne & 747 & 0.828 \\
\hline Sioux Falls & 718 & 0.796 \\
\hline South Bend & 695 & 0.771 \\
\hline Boston & 661 & 0.733 \\
\hline Pittsburgh & 646 & 0.716 \\
\hline Akron & 634 & 0.703 \\
\hline Denver & 625 & 0.693 \\
\hline Cleveland & 612 & 0.679 \\
\hline Minneapol is & 585 & 0.649 \\
\hline Hartford & 583 & 0.646 \\
\hline Grand Rapids & 574 & 0.636 \\
\hline Syracuse & 551 & 0.611 \\
\hline Providence & 531 & 0.589 \\
\hline Morristown & 486 & 0.539 \\
\hline Bismark & 486 & 0.539 \\
\hline Eau Claire & 459 & 0.509 \\
\hline Madison & 459 & 0.509 \\
\hline Milwaukee & 450 & 0.499 \\
\hline Pocatello & 436 & 0.483 \\
\hline Green Bay & 385 & 0.427 \\
\hline Minot & 369 & 0.409 \\
\hline Binghamton & 369 & 0.409 \\
\hline Concord & 347 & 0.385 \\
\hline Portland & 252 & 0.279 \\
\hline
\end{tabular}




\section{TABLE 3.3. Overal1 Site Ranking}

\begin{tabular}{|c|c|c|}
\hline city & $\begin{array}{l}\text { Mormalized Differential } \\
+ \text { Normalized CDD } \\
\end{array}$ & Ranking \\
\hline Tampa & 5.191 & 1 \\
\hline Port Arthur & 4.223 & 2 \\
\hline OKTahoma City & 4.211 & 3 \\
\hline Little Rock & 3.568 & 4 \\
\hline St, Louis & 3.286 & 5 \\
\hline Albuquerque & 2.925 & 5 \\
\hline Charleston & 2.691 & 7 \\
\hline Des Moines & 2.633 & 8 \\
\hline Columbia & 2.509 & 9 \\
\hline Newark & 2.500 & 10 \\
\hline Cincinnat $\mathrm{i}$ & 2.473 & 11 \\
\hline Knoxville & 2.384 & 12 \\
\hline Morristown & 2.283 & 13 \\
\hline Madison & 2.251 & 14 \\
\hline Milwaukee & 2.171 & 15 \\
\hline Providence & 2.166 & 16 \\
\hline Green Bay & 2.089 & 17 \\
\hline Fort Wayne & 2.020 & 18 \\
\hline Eau Claire & 1.923 & 19 \\
\hline Bismark & 1.898 & 20 \\
\hline Sioux Fatls & 1.895 & 21 \\
\hline A\}lentown & 1.880 & 22 \\
\hline Green Bay & 1.865 & 23 \\
\hline New York & 1.853 & 24 \\
\hline Pittsburgh & 1.755 & 25 \\
\hline Miles City & 1.750 & 26 \\
\hline Grand Rapids & 1.740 & 27 \\
\hline Mol ine & 1.739 & 28 \\
\hline Raleigh & 1.729 & 29 \\
\hline Roanoke & 1.678 & 30 \\
\hline Pocatelto & 1.823 & 31 \\
\hline Minneapolis & 1.616 & 32 \\
\hline Boston & 1.510 & 33 \\
\hline South Bend & 1.553 & 34 \\
\hline Pittsburgh & 1.442 & 35 \\
\hline Boston & 1.431 & 36 \\
\hline Moline & 1.430 & 37 \\
\hline Minot & 1.346 & 38 \\
\hline Syracuse & 1.319 & 39 \\
\hline Biaghamt on & 1.318 & 40 \\
\hline Providence & 1.315 & 41 \\
\hline Concord & 1.279 & $4 ?$ \\
\hline Hol ine & 1.2 .63 & 43 \\
\hline Mol ine & 1.245 & 44 \\
\hline Hartford & 1.215 & 45 \\
\hline Port Iand & 1.199 & 46 \\
\hline Binghamton & 1.177 & 47 \\
\hline pittsburgh & 1.013 & 48 \\
\hline Cleveland & 0.931 & 49 \\
\hline Akron & 0.703 & 50 \\
\hline Denver & 0.693 & 51 \\
\hline
\end{tabular}


TABLE 3.4. Characteristics of Sites Selected

$\begin{array}{ll}\text { 90th Percentile City: } & \text { St. Louis, Missouri } \\ \text { Peak rate: } & \$ 0.1477 / \mathrm{kWh} \\ \text { Off-peak rate: } & \$ 0.0459 / \mathrm{kWh} \\ \text { Differential: } & \$ 0.1018 / \mathrm{kWh} \\ \text { On-peak period: } & 1: 00 \mathrm{p} . \mathrm{m} . \text { to } 8: 00 \mathrm{p} . \mathrm{m} . \\ \text { Cooling-degree-days: } & 1474\end{array}$

50th Percentile City: Pittsburgh, Pennsylvania

Peak rate: $\$ 0.1045 / \mathrm{kWh}$

Off-peak rate: $\quad \$ 0.0405 / \mathrm{kWh}$

Differential $\$ 0.0640 / \mathrm{kWh}$

On-peak period: $8: 00 \mathrm{a} . \mathrm{m}$. to $8: 00 \mathrm{p} . \mathrm{m}$.

Cooling-degree-days: $\quad 646$

10th Percentile City: Hartford, Connecticut

Peak rate: $\quad \$ 0.1092 / \mathrm{kWh}$

off-peak rate: $\quad \$ 0.0742 / \mathrm{kWh}$

Differential: $\quad \$ 0.0350 / \mathrm{kwh}$

On-peak period: $8: 00 \mathrm{a} . \mathrm{m}$. to $8: 00 \mathrm{p} . \mathrm{m}$.

Cooling-degree-days: $\quad 583$ 



\subsection{BUILDING COOLING AND ELECTRIC LOADS}

Cooling loads and their associated electric loads and electric bills were calculated for ranch, two-story, and townhouse residences in St. Louis, Hartford, and Pittsburgh. This section provides additional detail regarding the analytical approach and presents and discusses the load modeling results.

\subsection{DOE-2}

A building energy simulation model known as DOE-2 (version DOE-2.1C) was used to calculate cooling coil loads, electric loads, and electric bills for the residences evaluated in this study. The model, originally called CalERDA, was developed in 1975 by Lawrence Berkeley Laboratory with funding from the State of California and the Energy Research and Development Administration. The model was renamed DOE-2 in 1979 with the creation of the U.S. Department of Energy. Lawrence Berkeley Laboratory has continued to develop the model, releasing four versions since 1979. The current version, DOE-2.1C, was released in 1985.

DOE-2 is a computer model that simulates energy use in buildings. It is typically used for building design, research, and code compliance analysis. DOE-2 was selected for this study because it calculates energy demands on an hourly basis. Hourly load calculations are required to accurately determine electric bilis when subject to a TOD rate structure, and hence determine the potential benefit of residential cool storage systems. A more detailed discussion of DOE-2 is contained in Overview of the DOE-2 Building Energy Analys is Program (Lawrence Berkeley Laboratory 1985).

The DOE-2 model required three types of input for this study: 1) hourly weather data, 2) building construction details, and 3) electric rates. In order for the results to reflect typical cooling loads, hourly weather data in the form of a Typical Meteorological Year (TMY) was used. A TMY is a hypothetical, composite year that represents typical weather patterns, means, and extremes for a given location. The composite year is created by combining actual months of hourly weather observations that most closely represent typical conditions. Typical meteorological year weather data were developed by the 
National Climatic Center, National Oceanic and Atmospheric Administration (1984).

Three buildings, which are described in detail below, were modeled by DOE-2. Building construction details were specified in terms of dimensions, floor plan, orientation, and insulation levels for each building type. Each building was equipped with a central air conditioning system of the type described in Section 2.2.1. Internal themal loads from appliances and occupants were assumed equal for all buildings.

For each of the three sites, the peak and off-peak electric rates and hourly periods were provided to the model. Two of the sites, Hartford and St. Louis, also offer flat rates to residential customers. The cost of electricity in the flat-rate cases was calculated by hand.

DOE-2 offers a large variety of output options to the user. For the purposes of this study, two types of output were specified: 1) hourly cooling and electric loads and 2) summaries of cooling and electric loads and electric bills. For each building and location, the model output lists the hourly cooling coil load (in Btus), the hourly cooling system electric load (in kwh), and the hourly fan electric load (also in $\mathrm{kWh}$ ). For each day of the cooling season, the model determined the minimum value, maximum value, sum, and average for the loads that were listed hourly. Monthly and yearly extremes, sums, and averages of the loads were also determined and included in the output. In addition to the energy usage data described above, the model also calculated monthly and annual electric bills in an economics subroutine.

\subsection{RESIDENTIAL BUILDINGS MODELED}

Three different buildings were modeled at each site to determine the impact of residential building size and type on the conventional cost of cooling and to generally broaden the applicability of the subsequent cost and performance requirements. These three building types are considered typical of the vast majority of single-family houses in the United States (Lawrence Berkeley Laboratory 1983). Specifically, the three buildings are a one-story ranch house of 1540 square feet, a two-story house of 2240 square feet, and a middleunit townhouse of 1200 square feet. 
After the most common building types were selected, construction details were specified for each building to accurately reflect typical building practices at each site. Energy saving design practices, such as roof or wall insulation levels, were obtained from the American Society of Heating, Refrigeration, and Air Conditioning Engineers (ASHRAE) Standard (ASHRAE 1980), which describes typical good building practices throughout the United States. Each of the buildings at all three sites have full basements. Including the basement, the two-story house has the greatest volume with 26,880 cubic feet. The ranch house is next at 26,640 cubic feet and the townhouse is smallest with a total of 14,400 cubic feet.

\subsection{COOLING SYSTEM PERFORMANCE}

Nominal electric loads were first determined from hourly building cooling loads based on an electric input ratio (EIR) (EIR $=1 / \mathrm{COP}=\mathrm{Btu}$ in $/ \mathrm{Btu}$ out) of 0.438 (ASHRAE 1980). This is equivalent to an energy efficiency ratio (EER) of 7.792. The actual electric loads were then calculated from the nominal loads by correcting for variations in inside and outside temperatures and for part-load operation of the air conditioning system. Equations that correct the nominal EIR for temperatures and part-load operation are built into the DOE-2 model and are reproduced below.

$$
\begin{aligned}
& \text { Corrected EIR }=(0.438) *\left(\mathrm{Z}_{1} / \mathrm{Z}_{2}\right) \\
& \mathrm{Z}_{1}=0.500-0.00766 \mathrm{~T}_{1}+0.0107 \mathrm{~T}_{2} \\
& \mathrm{~T}_{1}=\text { indoor wet bulb temperature, degrees Fahrenheit } \\
& \mathrm{T}_{2}=\text { outdoor dry bulb temperature, degrees Fahrenheit } \\
& \mathrm{Z}_{2}=0.125+0.875 \mathrm{X} \\
& \mathrm{X}=\text { hourly cooling load/hourly cooling capacity }
\end{aligned}
$$


Electric loads were also calculated for older, less efficient air conditioning systems that might be candidates for retrofitting with cool storage technology. Air conditioners have an expected useful life of approximately 15 years. According to the Air Conditioning and Refrigeration Institute (1985), residential air conditioning efficiency improved $16 \%$ over a recent 7 -year period (corresponding to one half of the average air conditioner life). Therefore, the cost of cooling a house with an older air conditioning system was modeled by inserting an EIR into DOE-2 that was $16^{\circ}$ greater than the nominal value of 0.438 .

\subsection{COOLING SYSTEM SIZING}

The DOE-2 model sized the air conditioning systems for each of the three buildings in each of the three sites using a sizing procedure nearly identical to the one recommended by ASHRAE. In this procedure, the thermal cooling loads required to maintain the building interior at a constant temperature for each hour of the cooling season are calculated. One day that includes an hour whose cooling load is greater than $97.5 \%$ of all hours in the year is selected as the design day. An air conditioning system capacity is then determined that can supply the necessary cooling for the 97.5 percentile hour. The air conditioning system size is then determined by rounding the required cooling capacity up to the nearest half ton.

For the buildings modeled in this study, air conditioner system size varies from 2 tons to 4 tons. Townhouses at all three sites require air conditioning systems of 2 tons, while the two-story house in St. Louis requires a system of 4-ton capacity. The ranch house in St. Louis has a 3-1/2-ton air conditioning system and the remaining four buildings all have 3 -ton systems.

\subsection{COOLING AND ELECTRIC LOAD RESULTS}

The results of modeling nine houses with the DOE-2 computer model are shown in Tables 4.1 and 4.2. Table 4.1 lists the annual cooling loads and annual electric loads for both new and older air conditioning equipment. Table 4.2 lists the annual electric bills for TOD and optional (in 5t. Louis and Hartford) flat-rate structures for both new and older air conditioning equipment. 
TABLE 4.1. Annual Cooling and Electric Loads

\begin{tabular}{|c|c|c|c|c|}
\hline City & Building & $\begin{array}{c}\text { Cooling Load, } \\
\text { MBtu }\end{array}$ & $\begin{array}{l}\text { Electric Load } \\
\text { New System }\end{array}$ & $\frac{\text { for Cooling, MBtu }}{\text { 01d System }}$ \\
\hline $\begin{array}{l}\text { St. Louis } \\
\text { St. Louis } \\
\text { St. Louis }\end{array}$ & $\begin{array}{l}\text { ranch } \\
\text { two-story } \\
\text { townhouse }\end{array}$ & $\begin{array}{l}23.47 \\
19.28 \\
16.34\end{array}$ & $\begin{array}{r}13.09 \\
11.03 \\
8.69\end{array}$ & $\begin{array}{l}15.36 \\
12.90 \\
10.17\end{array}$ \\
\hline $\begin{array}{l}\text { Hartford } \\
\text { Hartford } \\
\text { Hartford }\end{array}$ & $\begin{array}{l}\text { ranch } \\
\text { two-s tory } \\
\text { townhouse }\end{array}$ & $\begin{array}{l}6.56 \\
3.61 \\
4.42\end{array}$ & $\begin{array}{l}3.86 \\
2.28 \\
2.44\end{array}$ & $\begin{array}{l}4.53 \\
2.65 \\
2.86\end{array}$ \\
\hline $\begin{array}{l}\text { Pittsburgh } \\
\text { Pittsburgh } \\
\text { Pittsburgh }\end{array}$ & $\begin{array}{l}\text { ranch } \\
\text { two-story } \\
\text { townhouse }\end{array}$ & $\begin{array}{l}4.99 \\
2.46 \\
3.55\end{array}$ & $\begin{array}{l}2.83 \\
1.50 \\
1.94\end{array}$ & $\begin{array}{l}3.33 \\
1.77 \\
2.27\end{array}$ \\
\hline
\end{tabular}

TABLE 4.2. Annual Electric Bills for Cooling (1986 \$)

\begin{tabular}{|c|c|c|c|c|c|}
\hline & & New S & tem, \$ & old Sy & tem,$\$$ \\
\hline City & Building & Flat & TOD & & \\
\hline St. Louis & ranch & 330.12 & 374.51 & 387.37 & 438.70 \\
\hline St. Louis & two-story & 278.36 & 317.75 & 325.54 & 372.30 \\
\hline St. Louis & townhouse & 219.30 & 230.89 & 256.63 & 270.45 \\
\hline Hartford & ranch & 100.64 & 113.38 & 118.11 & 132.85 \\
\hline Hartford & two-story & 59.45 & 66.17 & 69.07 & 77.57 \\
\hline Hartford & townhouse & 63.55 & 69.79 & 74.48 & 81.76 \\
\hline Pittsburgh & ranch & NA & 71.4 & NA & 83.64 \\
\hline Pitts & $t w$ & NA & & NA & 42.24 \\
\hline & townhouse & NA & 44.89 & NA & 52.59 \\
\hline
\end{tabular}

The cooling loads in St. Louis were approximately four times those estimated for either Pittsburgh or Hartford. Although the St. Louis load was expected to be higher given its greater number of cooling-degree-days, the ratio was greater than the factor of two difference in cooling-degree-days predicted. Annual COPs ranged from a low of 1.582 in the Hartford two-story residence to 1.879 for the St. Louis townhouse. The impact of older equipment is reflected by a $16 \%$ to $17 \%$ increase in the electric load for all cases. 
The cooling load estimates calculated by DOE-2 do not follow the intuitive expectation that loads will rank according to floor area. In St. Louis, the cooling load is externally dominated by the climatic conditions; internal cooling loads are relatively insignificant. The two key factors affecting the external cooling load are external surface area and glazing area. In addition, the amount of roof area, where most of the heat gain is seen, is generally more important than wall area. The ranch house, with a larger roof area and larger window area, has a greater total cooling load than the twostory house (despite the larger exterior wall area of the two-story house), which, in turn, has a larger cooling load than the townhouse.

In Hartford and Pittsburgh, with their relatively mild summer climates, the total cooling load is dominated by the internal cooling loads, which were set equal for each of the three buildings. In general, the result is that all three loads in these cities are about equal and the ability to differentiate among the three buildings is close to the limits of accuracy available in DOE-2. Given the constant internal heating load, the smaller air volume of the townhouse tends to heat up faster. In addition, the much smaller wall area of the townhouse limits the release of internal heat to the outdoors via natural mechanisms. This results in a lower cooling balance point temperature. The effect is to cause the townhouse to heat up more quickly and require coolirg earlier in the day, or require cooling on days when the bigger buildings would not. This internal load effect is enough to outweigh the external load effect of the two-story house but not that of the ranch house.

In general, the city and residence-type rankings for the annual electric bills shown in Table 4.2 parallel the rankings seen for the electric load in Table 4.1. Both flat and TOD rate structures are offered to residential customers in St. Louis and Hartford. In both of these cities, the flat-rate structure resulted in a lower annual electrical bill for cooling. The lower flatrate figure was used in the base case calculations for determining the annualized cost of cooling for a conventional system because this represents the least-cost option to the homeowner. The impact on the annualized cost of cooling and the resultant initial capital cost and annual COP requirements of 
having the TOD rate required in St. Louis was evaluated as a sensitivity analysis to the standard assumption.

The hourly cooling loads on the peak day of the year are shown for the ranch houses in St. Louis, Pittsburgh, and Hartford in Tables 4.3, 4.4, and 4.5, respectively. As noted in Table 3.4, the on-peak period for St. Louis runs from 1:00 p.m. to 8:00 p.m. While the on-peak periods for Pittsburgh and Hartford both run from 8:00 a.m. to 8:00 p.m.

When the total daily cooling load for St. Louis is spread evenly over the off-peak period, the resultant peak hourly chill-generating capacity $(435,156 \mathrm{Btu} / 17$ hours $=25,597 \mathrm{Btu} /$ hour, neglecting thermal losses from the storage unit) is less than the peak hourly chill-generating capacity $(29,367$ Btu) required from a conventional system. This would seem to indicate that the TES-augmented system would not likely require a compressor that is larger than the conventional system. Note that the rated capacity of the conventional air conditioner selected by the DOE-2 model for the St. Louis ranch house was actually $42,000 \mathrm{Btu} / \mathrm{hour}$.

When the total daily cooling load for Pittsburgh is spread evenly over the off-peak period, the resultant peak hourly chill-generating capacity $(343,656 \mathrm{Btu} / 12$ hours $=28,638 \mathrm{Btu} /$ hour, neglecting thermal losses from the storage unit) is greater than the peak hourly chill-generating capacity $(25,192 \mathrm{Btu})$ required from a conventional system. This would seem to indicate that the TES-augmented system would likely require a compressor that is larger than the conventional system. Note that the rated capacity of the conventional air conditioner selected by the DOE-2 model for the Pittsburgh ranch house was actually $36,000 \mathrm{Btu} / \mathrm{hour}$.

When the total daily cooling load for Hartford is spread evenly over the off-peak period, the resultant peak hourly chill-generating capacity $(293,227 \mathrm{Btu} / 12$ hours $=24,436 \mathrm{Btu} /$ hour, neglecting thermal losses from the storage unit) is slightly less than the peak hourly chill-generating capacity $(25,498 \mathrm{Btu})$ required from a conventional system. This would seem to indicate that the TES-augmented system may not require a compressor that is larger 
TABLE 4.3. Hourly Cooling Loads on the Peak Cooling Day for the St. Louis Ranch House

\begin{tabular}{|c|c|c|}
\hline Date & Hour & Cooling Load, Btu \\
\hline $6 / 19$ & 1 & 7587 \\
\hline $6 / 19$ & 2 & 6445 \\
\hline $6 / 19$ & 3 & 5975 \\
\hline $6 / 19$ & 4 & 5415 \\
\hline $6 / 19$ & 5 & 6447 \\
\hline $6 / 19$ & 6 & 7765 \\
\hline $6 / 19$ & 7 & 14550 \\
\hline $6 / 19$ & 8 & 16225 \\
\hline $6 / 19$ & 9 & 18274 \\
\hline $6 / 19$ & 10 & 20445 \\
\hline $6 / 19$ & 11 & 24005 \\
\hline $6 / 19$ & 12 & 23898 \\
\hline $6 / 19$ & 13 & 25792 \\
\hline $6 / 19$ & 14 & 25996 \\
\hline $6 / 19$ & 15 & 27797 \\
\hline $6 / 19$ & 16 & 29367 \\
\hline $6 / 19$ & 17 & 28800 \\
\hline $6 / 19$ & 18 & 27378 \\
\hline $6 / 19$ & 19 & 26705 \\
\hline $6 / 19$ & 20 & 21987 \\
\hline $6 / 19$ & 21 & 20232 \\
\hline $6 / 19$ & 22 & 18171 \\
\hline $6 / 19$ & 23 & 15267 \\
\hline $6 / 19$ & 24 & 10633 \\
\hline \multicolumn{3}{|c|}{ Daily Summary (June 19) } \\
\hline \multicolumn{2}{|c|}{ Minimum hourly load } & 5415 \\
\hline \multicolumn{2}{|c|}{ Maximum hourly load } & 29367 \\
\hline \multicolumn{2}{|c|}{ Daily load } & 435156 \\
\hline \multicolumn{2}{|c|}{ Average hourly load } & 18131 \\
\hline
\end{tabular}


TABLE 4.4. Hourly Cooling Loads on the Peak Cooling Day for the Pittsburgh Ranch House

$\begin{array}{lcc}\text { Date } & \text { Hour } & \text { Cooling Load, Btu } \\ 7 / 21 & 1 & 4522 \\ 7 / 21 & 2 & 3252 \\ 7 / 21 & 3 & 2386 \\ 7 / 21 & 4 & 1161 \\ 7 / 21 & 5 & 1111 \\ 7 / 21 & 6 & 1467 \\ 7 / 21 & 7 & 6261 \\ 7 / 21 & 8 & 8479 \\ 7 / 21 & 9 & 12080 \\ 7 / 21 & 10 & 16931 \\ 7 / 21 & 11 & 20846 \\ 7 / 21 & 12 & 21231 \\ 7 / 21 & 13 & 21788 \\ 7 / 21 & 14 & 22396 \\ 7 / 21 & 15 & 22956 \\ 7 / 21 & 16 & 24080 \\ 7 / 21 & 17 & 24360 \\ 7 / 21 & 18 & 25192 \\ 7 / 21 & 19 & 25163 \\ 7 / 21 & 20 & 20790 \\ 7 / 21 & 21 & 18225 \\ 7 / 21 & 22 & 16409 \\ 7 / 21 & 23 & 13898 \\ 7 / 21 & 24 & 8672\end{array}$

Daily Summary (July 21)

Minimum hourly load

1111

Maximum hourly load

25192

Daily load

343656

Average hourly load

14319 
TABLE 4.5. Hourly Cooling Loads on the Peak Cooling Day for the Hartford Ranch House

\begin{tabular}{|c|c|c|}
\hline Date & Hour & Cooling Load, Btu \\
\hline $7 / 1$ & 1 & 4960 \\
\hline $7 / 1$ & 2 & 4759 \\
\hline $7 / 1$ & 3 & 4107 \\
\hline $7 / 1$ & 4 & 3779 \\
\hline $7 / 1$ & 5 & 3883 \\
\hline $7 / 1$ & 6 & 6249 \\
\hline $7 / 1$ & 7 & 12881 \\
\hline $7 / 1$ & 8 & 13782 \\
\hline $7 / 1$ & 9 & 15909 \\
\hline $7 / 1$ & 10 & 18224 \\
\hline $7 / 1$ & 11 & 20762 \\
\hline $7 / 1$ & 12 & 22796 \\
\hline $7 / 1$ & 13 & 23696 \\
\hline $7 / 1$ & 14 & 25498 \\
\hline $7 / 1$ & 15 & 22965 \\
\hline $7 / 1$ & 16 & 21784 \\
\hline $7 / 1$ & 17 & 14771 \\
\hline $7 / 1$ & 18 & 10981 \\
\hline $7 / 1$ & 19 & 10293 \\
\hline $7 / 1$ & 20 & 8689 \\
\hline $7 / 1$ & 21 & 7811 \\
\hline $7 / 1$ & 22 & 7095 \\
\hline $7 / 1$ & 23 & 5603 \\
\hline $7 / 1$ & 24 & 1951 \\
\hline \multicolumn{3}{|c|}{ Daily Summary (July 1) } \\
\hline \multicolumn{2}{|c|}{ Minimum hourly load } & 1951 \\
\hline \multicolumn{2}{|c|}{ Maximum hourly load } & 25498 \\
\hline \multicolumn{2}{|c|}{ Daily load } & 293227 \\
\hline \multicolumn{2}{|c|}{ Average hourly load } & 12218 \\
\hline
\end{tabular}


than the conventional system. Note that the rated capacity of the conventional air conditioner selected by the DOE-2 model for the Hartford ranch house was actually $36,000 \mathrm{Btu} / \mathrm{hour}$. 


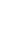




\subsection{SYSTEM LEVEL REQUIREMENTS}

As was discussed in Section 2.1, the general procedure for developing cost and performance requirements involves characterizing the cost, performance, and economic figure-of-merit for the conventional means of providing the service. This establishes the overall system level requirement. In the case of a residential cooling system, the annualized cost of cooling for conventional air conditioning systems ( $\$$ /MBtu) becomes the target figure-of-merit for TESaugmented systems.

\subsection{REFERENCE SYSTEM COSTS}

Initial capital, annual maintenance, and interim capital costs were estimated for each of the system sizes required by the building size and site combinations. Initial capital and interim capital (compressor replacement) estimates were developed from information in Gladstone, Humphreys, and Lunde (1987) and Mahoney (1987). Purchased equipment and installation labor charges are included in the initial cost figure, which covers the evaporator unit, condenser unit (condenser coil, fan, compressor, and mounting pad), interconnecting piping, and thermostat.

Annual maintenance costs were estimated by averaging the costs estimated for optimistic and pessimistic scenarios. The optimistic scenario included one routine annual maintenance call plus an allowance for the possible replacement of the compressor. The latter cost was estimated by multiplying the cost to replace the compressor by its failure rate (Commonwealth Edison Co. 1986). The conservative estimate included these cost elements plus an additional charge of $2 \%$ of initial capital to account for unforeseen repairs to other system components. The resultant maintenance cost estimates are consistent with what a standard rule-of-thumb (2\% to $6 \%$ of initial cost) would predict for maintenance of a "simple chemical process" (Peters and Timmerhaus 1980). Table 5.1 lists the initial capital, annual maintenance, and compressor replacement costs for each of the building and site combinations evaluated. 
IABLE 5.1. Reference Air Conditioning System Capital and Maintenance Costs (1987\$)

\begin{tabular}{|c|c|c|c|c|c|}
\hline City & Building & $\begin{array}{c}\text { Capacity, } \\
\text { Tons } \\
\end{array}$ & $\begin{array}{l}\text { Initial } \\
\text { Capital, } \\
\end{array}$ & $\begin{array}{c}\text { Annua 1 } \\
\text { Maintenance, } \\
\end{array}$ & $\begin{array}{c}\text { Compressor } \\
\text { Replacement, }\end{array}$ \\
\hline $\begin{array}{l}\text { St. Louis } \\
\text { St. Louis } \\
\text { St. Louis }\end{array}$ & $\begin{array}{l}\text { ranch } \\
\text { two-story } \\
\text { townhouse }\end{array}$ & $\begin{array}{l}3.5 \\
4.0 \\
2.0\end{array}$ & $\begin{array}{l}2685 \\
2990 \\
2040\end{array}$ & $\begin{array}{l}125 \\
130 \\
115\end{array}$ & $\begin{array}{l}875 \\
950 \\
700\end{array}$ \\
\hline $\begin{array}{l}\text { Hartford } \\
\text { Hartford } \\
\text { Hartford }\end{array}$ & $\begin{array}{l}\text { ranch } \\
\text { two-story } \\
\text { townhouse }\end{array}$ & $\begin{array}{l}3.0 \\
3.0 \\
2.0\end{array}$ & $\begin{array}{l}2380 \\
2380 \\
2040\end{array}$ & $\begin{array}{l}120 \\
120 \\
115\end{array}$ & $\begin{array}{l}800 \\
800 \\
700\end{array}$ \\
\hline $\begin{array}{l}\text { Pittsburgh } \\
\text { Pittsburgh } \\
\text { Pittsburgh }\end{array}$ & $\begin{array}{l}\text { ranch } \\
\text { two-story } \\
\text { townhouse }\end{array}$ & $\begin{array}{l}3.0 \\
3.0 \\
2.0\end{array}$ & $\begin{array}{l}2380 \\
2380 \\
2040\end{array}$ & $\begin{array}{l}120 \\
120 \\
115\end{array}$ & $\begin{array}{l}800 \\
800 \\
700\end{array}$ \\
\hline
\end{tabular}

\subsection{LIFE-CYCLE COST CALCULATIONS}

Separate life-cycle costs (system-level requirements) were calculated for TES-augmented systems competing with conventional systems in either a new construction or a retrofit situation. In a new construction scenario, a complete new conventional AC system is installed and operated over a nominal system life of 15 years. In a retrofit situation, a currently installed system is operated an additional 15 years. The retrofit system is presumed to be 7.5 years old at the start of the 15 -year operational period and will require replacement of the compressor after another 7.5 years. Power consumption is higher for the retrofit system during the first 7.5 years of operation wher: the older, less efficient equipment is used. Replacement of the compressor is assumed to make the retrofit system as efficient as the new system.

With the exception of the financing rate, the life-cycle cost estimates were calculated by using the methodology and economic assumptions specified in Brown et a1. (1987). The financing rate specified in Brown et al. (1987) for residential applications $(5.9 \%)$ is based on historical long-run rates of return rather than on current rates. The cost and performance requirements were calculated using a finance rate of $10 \%$, a figure representative of conventional home mortgage rates in recent years. The lower long-run rate of $5.9 \%$ was used 
in a sensitivity analysis conducted for the St. Louis ranch house. Estimates of initial capital, interim capital, maintenance, and electricity costs and the economic assumptions listed in Table 5.2 were input to the economic methodology to produce an estimate of the life-cycle cost of cooling, expressed in \$/MBtu. The resultant total life-cycle costs are shown in Table 5.3. Total life-cycle costs are broken into capital, maintenance, electricity, and property tax components in Tables 5.4 and 5.5 .

\section{IABLE 5.2. Economic Assumptions}

$\begin{array}{ll}\text { System life } & 15 \mathrm{yr} \\ \text { Property taxes } & 2 \% \text { of initial capital per yr } \\ \text { Financing rate } & 10.0 \% / \mathrm{yr} \\ \text { General inflation rate } & 3.1 \% / \mathrm{yr} \\ \text { Electricity escalation rate } & 2.5 \% / \mathrm{yr} \\ \text { Maintenance escalation rate } & 3.1 \% / \mathrm{yr} \\ \text { Capital escalation rate } & 3.1 \% / \mathrm{yr}\end{array}$

TABLE 5.3. Life-Cycle cost Results (annualized cost, $1986 \$ / M B t u$ )

\begin{tabular}{l} 
City \\
\hline St. Louis \\
St. Louis \\
St. Louis \\
Hartford \\
Hartford \\
Hartford \\
Pittsburgh \\
Pittsburgh \\
Pittsburgh
\end{tabular}

Building

ranch

two-story townhouse

ranch

two-story townhouse

ranch

two-story townhouse

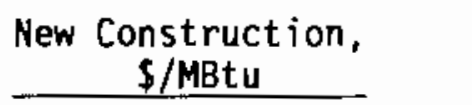

30

36

33

70

116

87

86

161

103
Retrofit \$/MBtu

23

26

24

44

68

53

52

89

61 
TABLE 5.4. Life-Cycle Cost Components for the New Construction Scenario (annualized cost, $1986 \$ / \mathrm{MBtu}$ )

\begin{tabular}{|c|c|c|c|c|c|c|}
\hline & & & & \$/MBtu & & \\
\hline City & Building & Capital & Maintenance & Electricity & Iaxes & Total \\
\hline St. Louis & ranch & 10 & 5 & 13 & 2 & 30 \\
\hline St. Louis & two-story & 13 & 7 & 14 & 2 & 36 \\
\hline St. Louis & townhouse & 11 & 7 & 13 & 2 & 33 \\
\hline Hartford & ranch & 31 & $1 B$ & 15 & 6 & 70 \\
\hline Hartford & two-story & 58 & 32 & 16 & 10 & 116 \\
\hline Hartford & townhouse & 40 & 25 & 14 & 8 & 87 \\
\hline Pittsburgh & ranch & 42 & 23 & 14 & 7 & 86 \\
\hline Pittsburgh & two-story & 85 & 47 & 14 & 15 & 161 \\
\hline Pittsburgh & townhouse & 50 & 32 & 12 & 9 & 103 \\
\hline
\end{tabular}

TABLE 5.5. Life-Cycle Cost Components for the Retrofit Scenario (annualized cost, $1986 \$ / M B t u$ )

\begin{tabular}{|c|c|c|c|c|c|c|}
\hline & & & & $\$ /$ MBtu & & \\
\hline City & Building & Capital & Maintenance & Electricity & Taxes & Tota? \\
\hline St. Louis & ranch & 1 & 5 & 15 & 2 & 2. \\
\hline St. Louis & two-story & 2 & 7 & 15 & 2 & 26 \\
\hline St. Louis & townhouse & 1 & 7 & 14 & 2 & 24 \\
\hline Hartford & ranch & 4 & 18 & 16 & 6 & 44 \\
\hline Hartford & two-story & 8 & 32 & 17 & 11 & 68 \\
\hline Hartford & townhouse & 6 & 25 & 15 & 7 & 53 \\
\hline Pittsburgh & ranch & 6 & 23 & 15 & 8 & 52 \\
\hline Pittsburgh & two-story & 11 & 47 & 16 & 15 & 8 \\
\hline Pittsburgh & townhouse & 7 & 31 & 14 & 9 & bl \\
\hline
\end{tabular}

New construction life-cycle cooling costs range from $\$ 30 / \mathrm{MBtu}$ for a ranch house in St. Louis to \$161/MBtu for a two-story house in Pittsburgh. Although the peak cooling load and total capital-related (initial or interim capital, maintenance, and property taxes) costs are roughly the same for each of the applications (see Table 5.1), the higher annual load in St. Louis (see Table 4.1) results in a lower cost per unit of cooling. Retrofit life-cycle cooling costs, with lower capital-related charges, are approximately $2 / 3$ to $3 / 4$ of the cost for the new construction scenario. 


\subsection{IES-AUGMENTED SYSTEM COST AND PERFORMANCE REQUIREMENTS}

The annualized cost of conventional cooling or system-level requirements calculated in Section 5.0 represent the overall cost of cooling that a TESaugmented system would have to meet or beat to be an economically attractive option. The overall cost comprises several cost elements, namely initial capital, interim capital, annual maintenance, annual electricity, and property taxes. The overall requirement can be achieved by an innumerable number of possible combinations of the above cost elements. In general, a tradeoff exists between the capital-related cost elements (initial capital, interim capital, annual maintenance, and property taxes) and the performance-related cost element (electricity); the same overall cost of cooling could be achieved by a system with a higher initial cost, but better performance (lower electric bill) or a system with a lower initial cost, but poorer performance (higher electric bill). This section defines alternative combinations of initial capital cost and round-trip energy efficiency (annual COP) for TES-augmented systems that yield the system-level requirements defined in Section 5.0.

\subsection{ANALYTICAL APPROACH}

As discussed in Section 2.2.4, adequate chill-storage capacity was assumed to be available to move all of the peak electric demand to off-peak. Annual maintenance and property tax rates were set at the same percent of initial capital as for each of the reference cooling systems. Thus, initial capital and annual performance are the only independent variables. Given these assumptions, the following procedure was conducted for each combination of site, building type, and new construction or retrofit situation:

1. Make an initial assumption for the TES-augmented system annual round-trip efficiency (COP)

2. Calculate the annual electricity consumption and cost

3. Solve for the TES-augmented system initial capital cost that results in the same system-level annualized cost of delivered chill.

Steps 1-3 were then repeated for other round-trip efficiency assumptions. The result of this procedure was a set of initial capital cost and annual 
performance pairs that could be plotted into a curve defining the boundary of acceptable cost and performance characteristics for TES-augmented cooling systems.

Separate cost and performance requirements were developed for one new construction and two retrofit scenarios for each combination of site and building type. In addition, three sensitivity cases were conducted for one site and building combination to determine the impact on cost and performance requirements of 1) having storage sized so that the chill-generator runs at full capacity for 24 hours on the peak day of the year, 2) basing the reference (conventional) system annual electric bill on the optional T00 rate structure rather than on the flat rate, and 3) lowering the financing rate from $10 \%$ to $5.9 \%$. Altogether, 30 separate scenarios were evaluated.

Separate cost and performance requirements were developed for new construction and retrofit scenarios because of the different system-level requirements for these two reference scenarios. In addition, separate cost and performance requirements were developed for two possible retrofit situations: 1) where TES would be an add-on to a conventional system and 2) where a new TES system would completely replace the conventional system. Separate requirements were necessary because performance changes after 7.5 years for the first case when the old compressor is replaced, whereas performance for the second case remains the same over the 15-year system life. Although TES could be either an add-on to a conventional system or a complete replacement for a conventional system in the new construction scenario, in either case the performance of the alternative remains constant through the 15-year system life.

An attempt was made to cover a reasonable range of cost and performance combinations without including unlikely combinations. For the new construction scenario, the upper design point was set at the same annual COP as the referenci? new construction system. The lower design point was set at the same initial cost as the reference new construction system. The upper and lower design points for the retrofit scenario/replacement system are the same as for the new construction scenario. For the retrofit scenario/add-on system, the upper design point was set at the same annual COP as the reference retrofit system. 
The lower design point was set at no cost for the add-on. Although a zero cost add-on is unlikely, no other obvious lower cost limit exists. In addition, this lower limit is essentially equivalent to the other two scenarios where a complete replacement system with TES is assumed to cost no more than the reference conventional system.

\subsection{COST AND PERFORMANCE REQUIREMENTS}

The initial capital cost and annual COP requirements for a TES-augmented system in the new construction scenario are listed in Table 6.1 and plotted in Figure 6.1. These requirements apply to the entire cooling system, including chill generation, storage, and delivery, and not just to the storage unit itself. System COP is defined as the total chill provided to the residence divided by the total electric energy input to the system on an annual basis. Table 6.1 identifies three different combinations of initial capital cost and annual COP for the TES-augmented system for each city and building pair. Each of these three combinations of initial capital cost and annual COP will result in a system with exactly the same life-cycle cost of cooling as the corresponding basis system (same city and building) for the new construction scenario. Thus, these are the cost and performance characteristics that a prospective TES-augmented system in a new construction scenario must meet to be economically attractive. Because the absolute cost and performance numbers for any city and building pair vary with the many site-specific factors, the differences in initial capital cost and annual COP between the TES-augmented systems and reference cooling systems are shown to help gauge the attractiveness of TES among the city and building pairs. The reference new construction system was chosen as the basis for comparison to highlight the incremental initial capital cost and/or reduction in system annual COP allowed with the TES-augmented system.

The data in Table 6.1 indicate that a TES-augmented system with the same annual COP as the reference system would be worth an additional $\$ 999$ above the initial cost of the reference system for a ranch house in St. Louis. Similarly, a TES-augmented system would be worth an additional $\$ 860$ and $\$ 624$, 
TABLE 6.1. New Construction Scenario Cost and Performance Requirements

\begin{tabular}{|c|c|c|c|c|c|}
\hline \multirow[b]{2}{*}{ City } & \multirow[b]{2}{*}{ Building } & \multicolumn{2}{|c|}{$\begin{array}{c}\text { TES-Augmented } \\
\text { System Requirements }(a)\end{array}$} & \multirow{2}{*}{\multicolumn{2}{|c|}{$\begin{array}{l}\text { Differentials } \\
\text { TES-Conventional }\end{array}$}} \\
\hline & & $\begin{array}{l}\text { Initial } \\
\text { Capital Cost }\end{array}$ & $\begin{array}{l}\text { Annual } \\
\text { COP }\end{array}$ & & \\
\hline St. Louis & ranch & $\begin{array}{l}3684 \\
3337 \\
2685\end{array}$ & $\begin{array}{l}1.794 \\
1.375 \\
0.956\end{array}$ & $\begin{array}{r}+999 \\
+\quad 652 \\
0\end{array}$ & $\begin{array}{l}0 \\
-0.419 \\
-0.838\end{array}$ \\
\hline St. Louis & two-story & $\begin{array}{l}3850 \\
3551 \\
2990\end{array}$ & $\begin{array}{l}1.747 \\
1.339 \\
0.931\end{array}$ & $\begin{array}{r}+860 \\
+561 \\
0\end{array}$ & $\begin{array}{l}0 \\
-0.408 \\
-0.816\end{array}$ \\
\hline St. Louis & townhouse & $\begin{array}{l}2664 \\
2447 \\
2040\end{array}$ & $\begin{array}{l}1.879 \\
1.440 \\
1.002\end{array}$ & $\begin{array}{r}+624 \\
+407 \\
0\end{array}$ & $\begin{array}{c}0 \\
-0.439 \\
-0.877\end{array}$ \\
\hline Hartford & ranch & $\begin{array}{l}2486 \\
2438 \\
2380\end{array}$ & $\begin{array}{l}1.700 \\
1.559 \\
1.418\end{array}$ & $\begin{array}{r}+106 \\
+\quad 58 \\
0\end{array}$ & $\begin{array}{l}0 \\
-0.141 \\
-0.282\end{array}$ \\
\hline Hartford & two-story & $\begin{array}{l}2442 \\
2414 \\
2380\end{array}$ & $\begin{array}{l}1.582 \\
1.450 \\
1.319\end{array}$ & $\begin{array}{r}+62 \\
+\quad 34 \\
0\end{array}$ & $\begin{array}{c}0 \\
-0.132 \\
-0.263\end{array}$ \\
\hline Hartford & townhouse & $\begin{array}{l}2104 \\
2075 \\
2040\end{array}$ & $\begin{array}{l}1.814 \\
1.663 \\
1.513\end{array}$ & $\begin{array}{r}+\quad 64 \\
+\quad 35 \\
\end{array}$ & $\begin{array}{l}0 \\
-0.151 \\
-0.301\end{array}$ \\
\hline Pittsburgh & ranch & $\begin{array}{l}2620 \\
2543 \\
2380\end{array}$ & $\begin{array}{l}1.767 \\
1.298 \\
0.829\end{array}$ & $\begin{array}{r}+240 \\
+163 \\
0\end{array}$ & $\begin{array}{l}0 \\
-0.469 \\
-0.938\end{array}$ \\
\hline Pittsburgh & two-story & $\begin{array}{l}2496 \\
2457 \\
2380\end{array}$ & $\begin{array}{l}1.643 \\
1.227 \\
0.810\end{array}$ & $\begin{array}{r}+116 \\
+\quad 77 \\
0\end{array}$ & $\begin{array}{l}0 \\
-0.416 \\
-0.833\end{array}$ \\
\hline Pittsburgh & townhouse & $\begin{array}{l}2174 \\
2128 \\
2040\end{array}$ & $\begin{array}{l}1.834 \\
1.386 \\
0.938\end{array}$ & $\begin{array}{r}+134 \\
+\quad 88 \\
0\end{array}$ & $\begin{array}{l}0 \\
-0.448 \\
-0.896\end{array}$ \\
\hline
\end{tabular}

(a) These requirements apply to the entire cooling system including chill generation, storage, and delivery.

(b) All costs in 1986 dollars. 


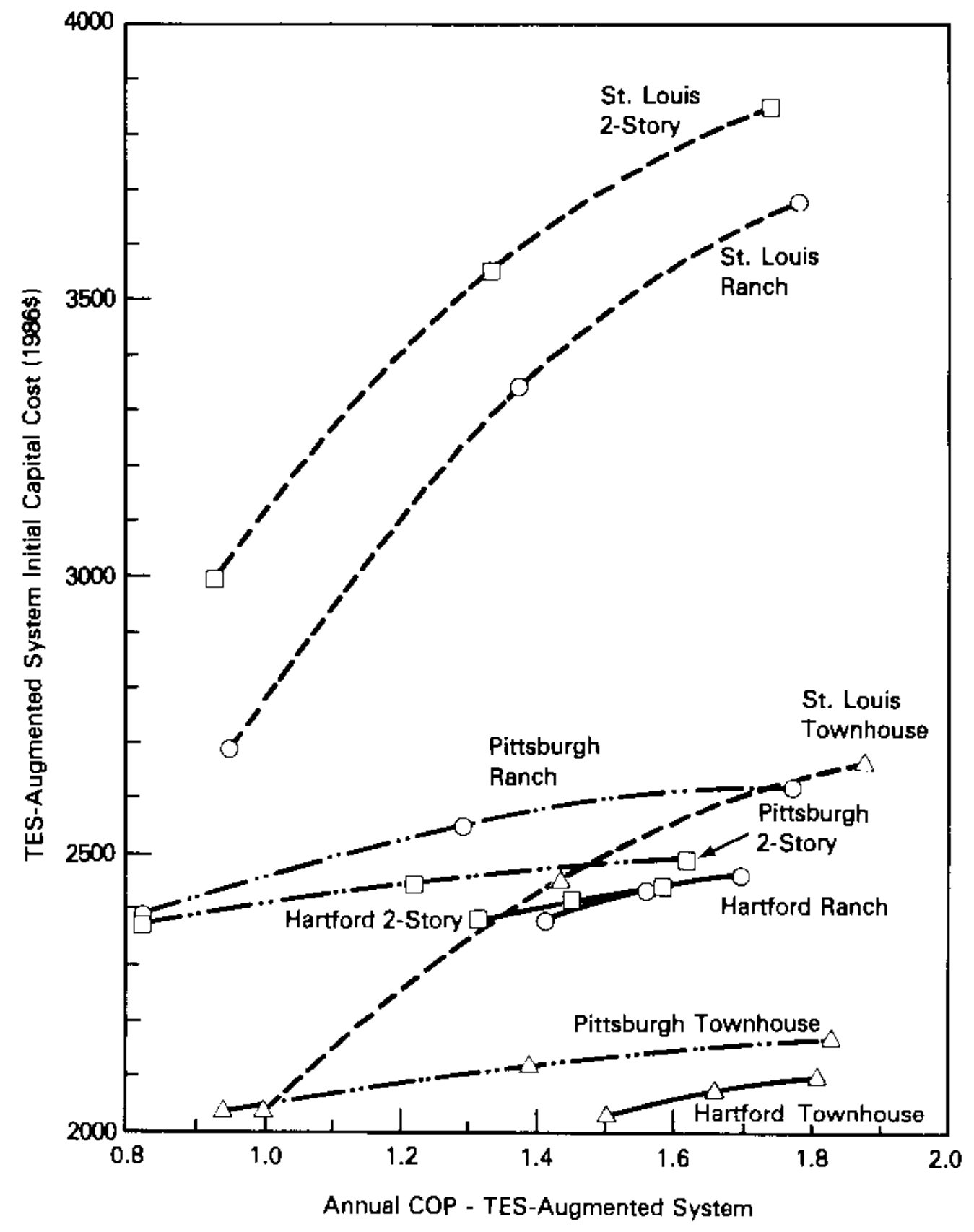

FIGURE 6.1. Initial Capital Cost and Annual COP Requirements for a TESAugmented System in the New Construction Scenario 
respectively, for two-story and townhouse residences in St. Lou is. Alternatively, a TES-augmented system with the same initial cost as the reference system would only need to have an annual COP roughly half that of the reference system for any of the three building types in St. Louis.

Conditions are less attractive in Hartford and Pittsburgh. Here the additional worth of a TES-augmented system with a COP equal to its reference system ranges from $\$ 62$ for the two-story house in Hartford up to $\$ 240$ for the ranch house in Pittsburgh. St. Louis is more attractive because of its higher annual cooling load and large electric rate differential for moving to offpeak. Pittsburgh is more attractive for TES than Hartford due to its higher electric rate differential, even though it has the lowest annual cooling load. For TES-augmented systems with the same initial cost as the reference system, the annual COP need only be roughly $50 \%$ of the reference system in Pittsburgh, much like the case in St. Louis. In Hartford, where the benefit per kwh of shifting the electric load off-peak is lower than for either St. Louis or Pittsburgh, the annual COP required for a TES-augmented system with the same initial cost as the reference system must be greater than $80 \%$ of the COP for the reference system. Although the order of attractiveness for the three cities is consistent with the rankings developed in the site selection process, the relative attractiveness of the $S t$. Louis site is even greater than the rankings predicted. This result can be attributed to the fact that the actual cooling load in St. Louis, compared to Pittsburgh and Hartford, was greater than predicted by their relative number of cooling-degree-days.

The initial capital cost and annual COP requirements for a TES-augmented system in the retrofit/replacement system scenario are listed in Table 6.2. Again, these requirements apply to the entire cooling system, including chill generation, storage, and delivery, and not just to the storage unit itself. System COP is still defined as the total chill provided to the residence divided by the total electric energy input to the system on an annual basis. Table 6.2 identifies one combination of initial capital cost and annual cop for the TES-augmented system for each site and building pair. Each of these combinations of initial capital cost and annual COP will result in a system with 
TABLE 6.2. Retrofit/Replacement System Scenario Cost and Performance Requirements

\begin{tabular}{|c|c|c|c|c|c|}
\hline \multirow[b]{2}{*}{ City } & \multirow[b]{2}{*}{ Building } & Initial & Annual & \multirow{2}{*}{\multicolumn{2}{|c|}{ TES-Conventiona 1}} \\
\hline & & Capital Cost ${ }^{(0)}$ & COP & & \\
\hline St. Louis & ranch & 2535 & 1.794 & -150 & 0 \\
\hline St. Louis & two-story & 2473 & 1.747 & -517 & 0 \\
\hline St. Louis & townhouse & 1830 & 1.879 & -210 & 0 \\
\hline Hartford & ranch & 1370 & 1.700 & -1010 & 0 \\
\hline Hartford & two-story & 1295 & 1.582 & -1085 & 0 \\
\hline Hartford & townhouse & 1170 & 1.814 & -870 & 0 \\
\hline Pittsburgh & ranch & 1484 & 1.767 & -896 & 0 \\
\hline Pittsburgh & two-story & 1335 & 1.643 & -1045 & 0 \\
\hline Pittsburgh & townhouse & 1230 & 1.834 & -810 & 0 \\
\hline
\end{tabular}

(a) These requirements apply to the entire cooling system, inciuding chill generation, storage, and delivery.

(b) All costs in 1986 dollars.

exactly the same life-cycle cost of cooling as the corresponding reference system (same city and building) for the retrofit scenario. Thus, these are the cost and performance characteristics that a prospective TES-augmented system in a retrofit/replacement scenario must meet to be economically attractive. Again, because the absolute cost and performance numbers for any city and building pair vary with the many site-specific factors, the differences in initial capital cost and annual COP between the TES and conventional cooling systems are shown to help gauge the attractiveness of TES among the city and building pairs. The reference new construction system was chosen as the basis for comparison to highlight the incremental initial capital cost and/or reduction in system annual COP allowed with the replacement TES-augmented system. 
The data in Table 6.2 indicate that the prospects for TES in the retrofit/replacement system scenario are extremely limited. For each of the nine pairs of cities and buildings, the TES-augmented replacement system would have to be less expensive than its corresponding conventional unit, while achieving the same annual COP or a higher annual COP for the same cost. Neither of these two requirements, while possible, are likely to be met.

The initial capital cost and annual COP requirements for a TES-augmented system in the retrofit/add-on system scenario are listed in Table 6.3 and plotted in Figure 6.2. The initial capital cost requirement includes the cost of the add-on (storage) unit plus any other costs associated with modifications required of the conventional equipment being retrofit. The annual COP requirement, on the other hand, applies to the entire resulting system, including chill generation, storage, and delivery. System COP is still defined as the total chill provided to the residence divided by the total electric energy input to the system on an annual basis. Table 6.3 identifies three combinations of initial capital cost and annual COP for the TES-augmented system for each site and building pair. Each of these combinations of initial capital cost and annual COP will result in a system with exactly the same life-cycle cost of cooling as the corresponding reference system (same city and building) for the retrofit scenario. Thus, these are the cost and performance characteristics that a prospective TES-augmented system must meet to be economically attractive in the retrofit/add-on system scenario. Again, becaus' the absolute cost and performance numbers for any city and building pair vary with the many site-specific factors, the differences in initial capital cost and annual COP between the TES systems and the reference cooling systems are shown to help gauge the attractiveness of TES anong the city and building pairs. The reference retrofit system was chosen as the basis for comparison to highlight the initial capital cost and/or reduction in system annual cop allowed with the add-on TES unit.

The data in Table 6.3 indicate that the general trends and prospects for TES in a retrofit/add-on system are similar to those seen in Table 6.1 for the new construction scenario. The explanations for each of the trends are identical to those described for the new construction scenario and are not repeatec. here. 
IABLE 6.3. Retrofit/Add-On System Scenario Cost and Performance Requirements

\begin{tabular}{|c|c|c|c|c|c|}
\hline City & Building & \multicolumn{2}{|c|}{$\begin{array}{c}\text { TES-Augmented } \\
\text { System Requirements }\end{array}$} & \multicolumn{2}{|c|}{$\begin{array}{c}\text { Differential } \\
\text { TES-Conventional }\end{array}$} \\
\hline St. Louis & ranch & $\begin{array}{r}1105 \\
720 \\
0\end{array}$ & $\begin{array}{l}1.662 \\
1.274 \\
0.886\end{array}$ & $\begin{array}{r}+1105 \\
+720 \\
0\end{array}$ & $\begin{array}{l}0 \\
-0.388 \\
-0.776\end{array}$ \\
\hline St. Louis & two-story & $\begin{array}{r}951 \\
620 \\
0\end{array}$ & $\begin{array}{l}1.621 \\
1.242 \\
0.864\end{array}$ & $\begin{array}{r}+951 \\
+620 \\
0\end{array}$ & $\begin{array}{c}0 \\
-0.379 \\
-0.757\end{array}$ \\
\hline St. Louis & townhouse & $\begin{array}{r}689 \\
450 \\
0\end{array}$ & $\begin{array}{l}1.743 \\
1.335 \\
0.928\end{array}$ & $\begin{array}{r}+689 \\
+450 \\
0\end{array}$ & $\begin{array}{l}0 \\
-0.408 \\
-0.815\end{array}$ \\
\hline Hartford & ranch & $\begin{array}{r}117 \\
64 \\
0\end{array}$ & $\begin{array}{l}1.575 \\
1.443 \\
1.311\end{array}$ & $\begin{array}{r}117 \\
+\quad 64 \\
0\end{array}$ & $\begin{array}{l}0 \\
-0.132 \\
-0.264\end{array}$ \\
\hline Hartford & two-story & $\begin{array}{r}63 \\
34 \\
0\end{array}$ & $\begin{array}{l}1.459 \\
1.347 \\
1.235\end{array}$ & $\begin{array}{r}+63 \\
+\quad 34 \\
0\end{array}$ & $\begin{array}{c}0 \\
-0.112 \\
-0.224\end{array}$ \\
\hline Hartford & townhouse & $\begin{array}{r}70 \\
38 \\
0\end{array}$ & $\begin{array}{l}1.681 \\
1.542 \\
1.403\end{array}$ & $\begin{array}{r}+\quad 70 \\
+\quad 38 \\
0\end{array}$ & $\begin{array}{l}0 \\
-0.139 \\
-0.278\end{array}$ \\
\hline Pittsburgh & ranch & $\begin{array}{r}264 \\
180 \\
0\end{array}$ & $\begin{array}{l}1.633 \\
1.201 \\
0.770\end{array}$ & $\begin{array}{r}+264 \\
+180 \\
0\end{array}$ & $\begin{array}{c}0 \\
-0.432 \\
-0.863\end{array}$ \\
\hline Pittsburgh & two-story & $\begin{array}{r}126 \\
84 \\
0\end{array}$ & $\begin{array}{l}1.518 \\
1.137 \\
0.755\end{array}$ & $\begin{array}{r}+126 \\
+\quad 84 \\
0\end{array}$ & $\begin{array}{c}0 \\
-0.381 \\
-0.763\end{array}$ \\
\hline Pittsburgh & townhouse & $\begin{array}{r}149 \\
99 \\
0\end{array}$ & $\begin{array}{l}1.700 \\
1.282 \\
0.864\end{array}$ & $\begin{array}{r}+149 \\
+\quad 99 \\
0\end{array}$ & $\begin{array}{l}0 \\
-0.418 \\
-0.836\end{array}$ \\
\hline
\end{tabular}

\footnotetext{
(a) The initial capital cost requirement covers the cost of the add-on (storage) system plus any other costs associated with modifying the system being retrofit. The annual COP requirement applies to the entire resulting system, including all generation, storage, and delivery.

(b) All costs in 1986 dollars.
} 


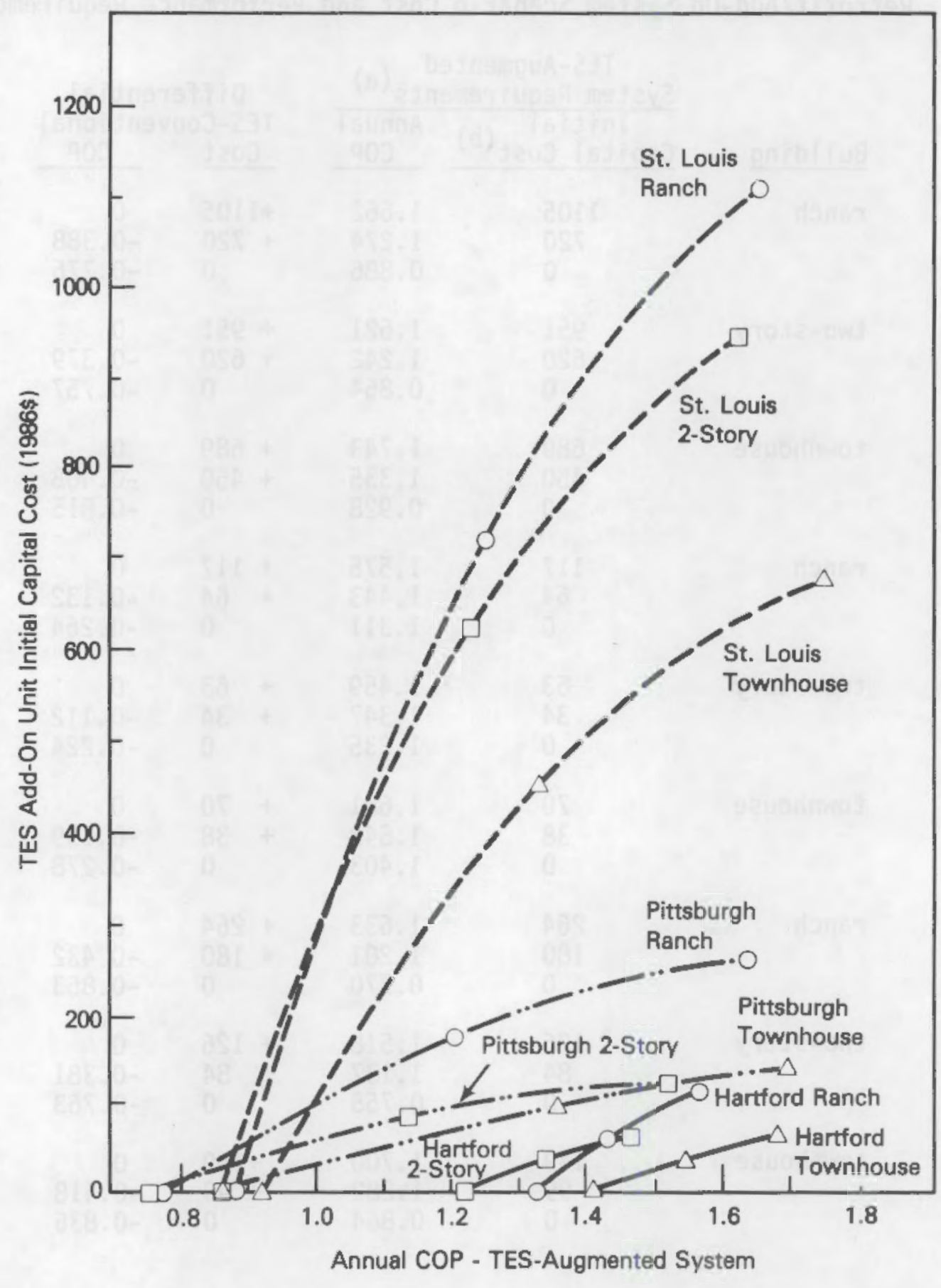

FIGURE 6.2. Initial Capital Cost and Annual COP Requirements for a TESAugmented System in the Retrofit/Add-on System Scenario 
A TES add-on resulting in the same annual COP as the reference system would be worth an additional $\$ 1105, \$ 951$, and $\$ 689$, respectively, for ranch, two-story, and townhouse residences in St. Louis. Alternatively, if the TES add-on was free, the resultant system would only need to have an annual COP roughly half that of the reference system for any of the three building types in St. Louis.

Again, conditions are less attractive in Hartford and Pittsburgh. Here the additional worth of an add-on TES unit resulting in a system with a COP equal to its reference system ranges from $\$ 63$ for the two-story house in Hartford to $\$ 264$ for the ranch house in Pittsburgh. If the TES add-on was free, the annual COP for the resultant system need only be roughly $50 \%$ of the reference system in Pittsburgh. In Hartford, the annual COP required for the resultant system for a free TES is roughly $80 \%$ of the COP for the reference system.

Because the initial capital cost requirements for the retrofit/add-on system scenario primarily encompass only the cost of the add-on (storage) unit, the cost requirements for this scenario are also expressed in $\$ /$ tonhour and $\$ / \mathrm{milli}$ ion Btu in Table 6.4 .

\subsection{SENSITIVITY CASES}

The initial capital cost and annual COP requirements reported above were developed under the following three (among other) ground rules or assumptions. 1) Adequate storage capacity is available with the TES-augmented systems to allow all of the peak electric demand to be moved off-peak. 2) For utilities offering a choice between flat and T00 rates (St. Louis and Hartford), the rate structure yielding the lower annual electric bill for cooling (the flat rate, for each of the buildings in St. Louis and Hartford) is used for the reference (conventional) system. 3) Financing costs are based on recent loan rates.

Sensitivity cases were evaluated to look at the effect on the cost and performance requirements when these three assumptions were independently altered. Specifically, initial capital cost and annual COP requirements were calculated under the following alternative conditions. 1) Storage capacity 
TABLE 6.4. Retrofit/Add-On System Scenario Cost and Performance Requirements: Alternative Cost Units

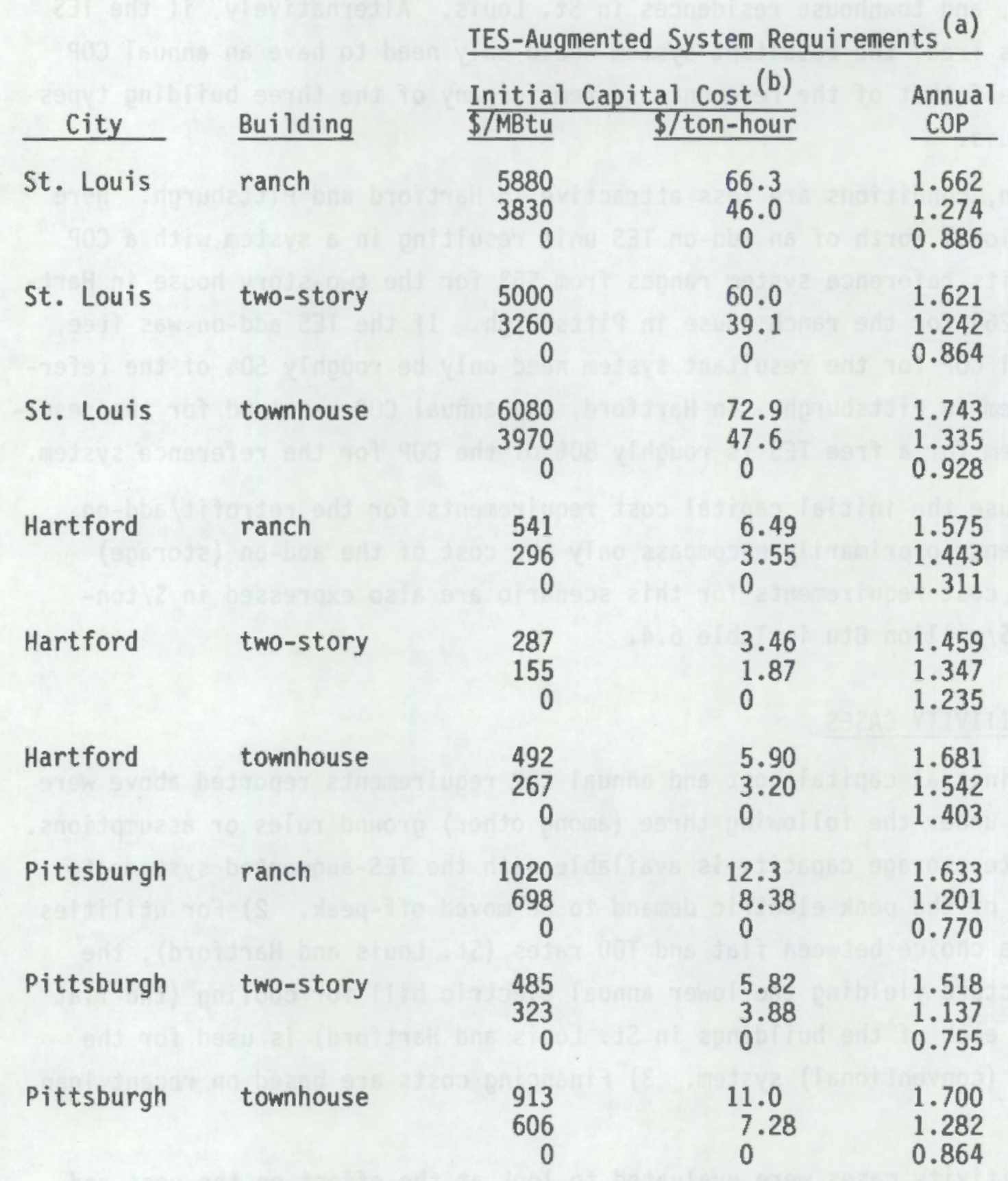

\footnotetext{
(a) The initial capital cost requirement covers the cost of the add-on (storage) system plus any other costs associated with modifying the system being retrofit. The annual COP requirement applies to the entire resulting system, including all generation, storage, and delivery.

(b) All costs in 1986 dollars.
} 
for the TES-augmented systems is sized so that the chill-generator runs 24 hours a day at a constant rate on the peak day of the year. 2) The reference (conventional) system electric bill for cooling is based on TOD rates. 3) Financing costs are based on historical long-run average loan rates.

\subsubsection{Alternative Storage Sizing}

The initial capital cost and annual COP requirements reported in Section 6.2 were developed under the assumption that adequate storage capacity would be available with the TES-augmented system to allow all of the electric demand to be moved to the off-peak period. While this assumption allows the maximum possible savings in the electric bill, it would generally require a larger chill-generator and storage unit than might be required with some other design options. As a sensitivity analysis to the general storage sizing assumption, alternative cost and performance requirements were determined under the assumption that storage was sized so that the chill-generator would run 24 hours a day at a constant rate on the peak cooling day of the year.

The sensitivity analysis was conducted for the St. Louis ranch house. This particular house has a peak daily cooling load of 435,000 Btu, or about $18,000 \mathrm{Btu} /$ hour for a chill-generator operating continuously for 24 hours. In St. Louis, the off-peak period lasts for 17 hours. Thus, approximately 306,000 Btu of chill could be generated during the off-peak period. Over an entire cooling season, a day-by-day analysis of the cooling loads indicated that all but $1.47 \mathrm{MBtu}$ of the total $23.47 \mathrm{MBtu}$ cooling load for the St. Louis ranch house could still be met by off-peak chill generation. A new set of initial capital cost and annual COP requirements were calculated from this basis for the new construction and retrofit scenarios.

Sensitivity and base-case figures are compared in Figure 6.3 and Table 6.5. For each scenario (new construction, retrofit/replacement, and retrofit/ add-on) the impact of the alternative storage sizing assumption is initial capital cost and annual COP requirements that are slightly more restrictive than the requirements calculated for the base-case design assumption; i.e., at the same initial capital cost, the annual COP must be higher and at the 


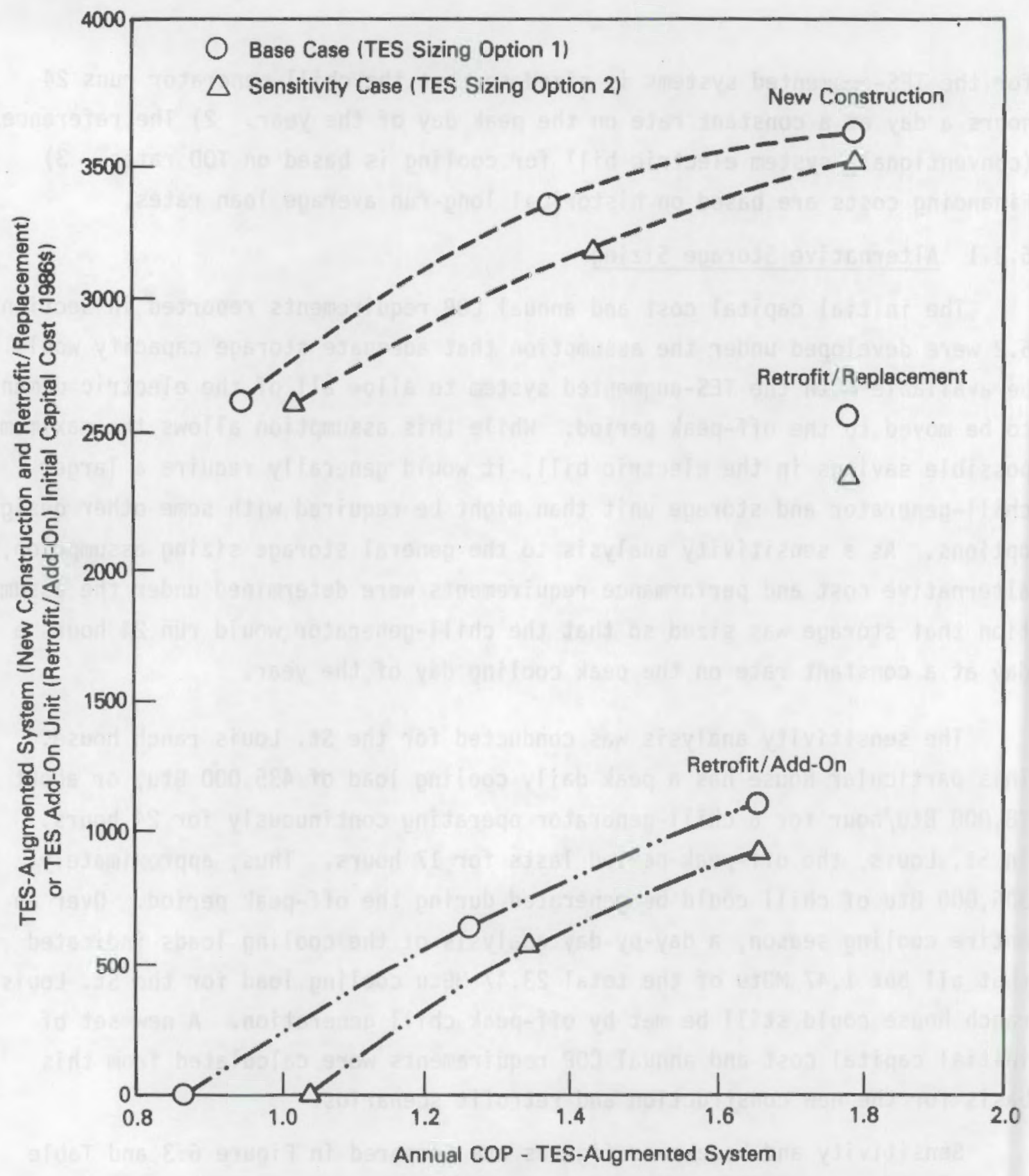

FIGURE 6.3. Storage-Sizing Sensitivity and Base-Case Figures 
TABLE 6.5. Alternative Storage Sizing Results, St. Louis Ranch House (all costs in 1986 dollars)

\begin{tabular}{|c|c|c|}
\hline System & $\begin{array}{c}\text { Initial Capital } \\
\text { Cost, } \$ \\
\end{array}$ & Annual COP \\
\hline \multicolumn{3}{|l|}{ New construction } \\
\hline Reference ${ }^{(a)}$ & 2685 & 1.794 \\
\hline Base case ${ }^{(b)}$ & $\begin{array}{l}3684 \\
3337 \\
2685\end{array}$ & $\begin{array}{l}1.794 \\
1.375 \\
0.956\end{array}$ \\
\hline Sensitivity case ${ }^{(c)}$ & $\begin{array}{l}3525 \\
3207 \\
2685\end{array}$ & $\begin{array}{l}1.794 \\
1.442 \\
1.089\end{array}$ \\
\hline \multicolumn{3}{|l|}{ Retrofit/replacement } \\
\hline Reference & 2685 & 1.794 \\
\hline Base case & 2535 & 1.794 \\
\hline Sensitivity case & 2376 & 1.794 \\
\hline \multicolumn{3}{|l|}{ Retrofit/add-on } \\
\hline Reference & 0 & 1.662 \\
\hline Base case & $\begin{array}{r}1105 \\
720 \\
0\end{array}$ & $\begin{array}{l}1.662 \\
1.274 \\
0.886\end{array}$ \\
\hline Sensitivity case & $\begin{array}{r}929 \\
600 \\
0\end{array}$ & $\begin{array}{l}1.662 \\
1.352 \\
1.042\end{array}$ \\
\hline
\end{tabular}

\footnotetext{
(a) Conventional air conditioning system

(b) TES system with storage sized to allow all electric demand to be moved off-peak.

(c) TES system with storage sized so that the chill-generator operates 24 hours a day at a constant rate on the peak cooling day of the year.
} 
same annual COP, the initial capital cost must be lower. Of course, these requirements may be just as easy, if not easier, to achieve because both the chill-generator and storage unit would be smaller and less costly under the sensitivity case assumptions. The optimum storage size depends on the actual cost and performance of the TES-augmented cooling system and the actual building cooling load and utility rate structure. This will likely be a unique storage size for every installation considered.

\subsubsection{Alternative Rate Structure}

The initial capital cost and annual COP requirements reported in Section 6.2 were developed under the assumption that the reference (conventional) system would be operated with the rate structure that resulted in the lowest annual electric bill for cooling, where alternative rate structures were available. Both flat and TOO rate structures are available in St. Louis and Hartford, whereas in Pittsburgh the TOD rate structure is mandatory. For each of the six buildings evaluated in St. Louis and Hartford, the annual electric bill for cooling was determined to be lower with the flat rate for the reference (conventional) system. For these two cities, the cost and performance requirements of the TES-augmented systems were then determined by incorporating the effects of switching from a flat rate to a TOD rate as well as the effects of implementing TES to take advantage of the TOD rate structure. No attempt was made in this study to characterize the cost or savings associated with a switch from flat to TOD rates and the resulting impact on the use of electricity in non-cooling applications.

As a sensitivity analysis, initial capital cost and annual COP requirements were calculated for the St. Louis ranch house based on the annual electric bill for the reference (conventional) system using TOD rates. When TOD rates are already in place, any potential impact on the use and cost of electricity in non-cooling applications because of switching from flat to TOD rates becomes moot.

Sensitivity and base-case figures are compared in Figure 6.4 and Table 6.6. For each scenario (new construction, retrofit/replacement, and retrofit/ add-on), the impact of assuming a TOD rate structure for the reference system 


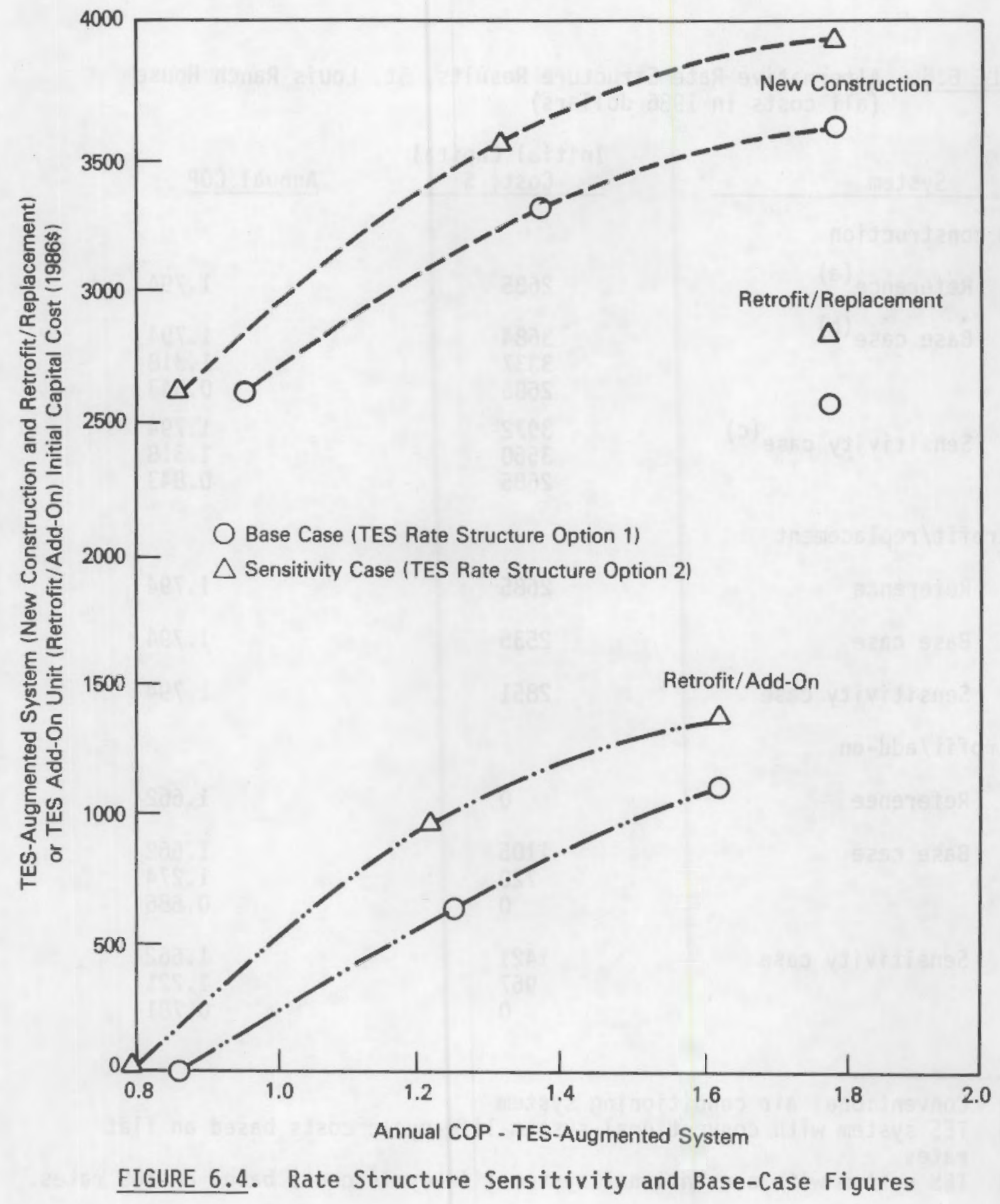


TABLE 6.6. Alternative Rate Structure Results, St. Louis Ranch House (all costs in 1986 dollars)

\section{System}

New construction

$$
\text { Reference }^{(\mathrm{a})}
$$

Base case ${ }^{(b)}$

Sensitivity case ${ }^{(c)}$

Retrofit/replacement

Reference

Base case

Sensitivity case

Retrofit/add-on

Reference

Base case

Sensitivity case

\section{Initial Capital Cost.}

Annual COP

2685

1.794

3684

3337

2685

3972

3560

2685

2685

1.794

2535

1.794

2851

1.794

0

1.662

1105

720

0

1421

967

0
1.794

1.318

0.843

1.794

1.318

0.843

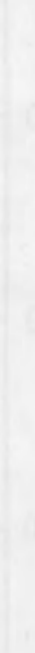


in the St. Louis ranch house is initial capital cost and annual cop requirements that are less restrictive than the requirements calculated for the base-case assumption; i.e., at the same initial cost, the allowable annual COP is lower and at the same annual COP, the allowable initial capital cost is higher. This impact on the cost and performance requirements follows from the increase in the electric bill for the reference (conventional) system under the TOD rate sensitivity assumption. In general, any increase in the on-peak part of the electric bill for cooling will result in cost and performance requirements for the TES-augmented system that are less restrictive.

\subsubsection{A1ternative Financing Rate}

The initial capital cost and annual COP figures reported in Section 6.2 are the current requirements of TES-augmented cooling systems. These requirements were calculated assuming a finance rate of $10 \%$, a figure representative of conventional home mortgage rates in the past couple of years. A sensitivity analysis was conducted for the St. Louis ranch house to determine the impact on cost and performance requirements if financing were available at $5.9 \%$, the historical long-run average home mortgage rate (Brown et al. 1987).

Sensitivity and base-case figures are compared in Figure 6.5 and Table 6.7. For each scenario (new construction, retrofit/replacement, and retrofit/add-on), the results of the alternative financing assumption for the St. Louis ranch house are initial capital costs and annual cop requirements that are slightly less restrictive than the requirements calculated for the base-case assumption; i.e., at the same initial cost, the allowable annual COP is lower and at the same annual COP, the allowable initial capital cost is higher. This impact on the cost and performance requirements follows directly from the fact that lowering the financing costs makes the more capitalintensive TES-augmented systems more attractive. 


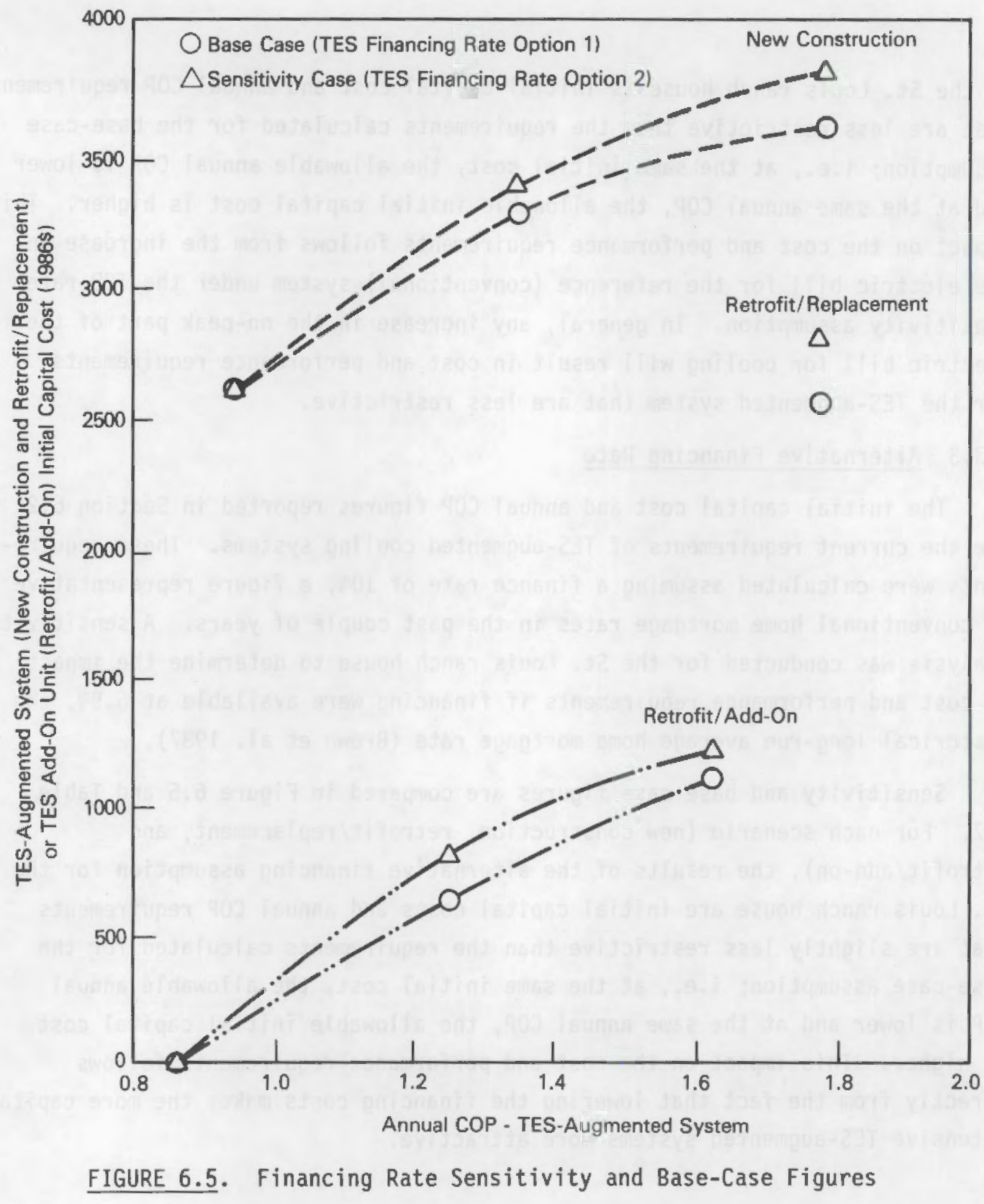


TABLE 6.7. Alternative Financing Rate Results, St. Louis Ranch House (all costs in 1986 dollars)

\section{System}

New construction

$$
\begin{aligned}
& \text { Reference } \\
& \text { Base case } \\
& (b)
\end{aligned}
$$

Sensitivity case ${ }^{(c)}$

3811

3419

2685

\section{5}

3684

3337

2685

3811

Retrofit/replacement

Reference

2685

Base case

Sensitivity case

Retrofit/add-on

Reference

0

2535

2836

Base case

\section{Initial Capital \\ Cost,}

Annual COP

\footnotetext{
Sensitivity case

1105
720

1105
720
0

(a) Conventional air conditioning system

(b) TES system with $10 \%$ financing.

(c) TES system with $5.9 \%$ financing.
}

1.794

1.794

1.375

0.956

1.794

1.375

0.956

$\begin{array}{crr}\text { Reference } & 2685 & 1.794 \\ \text { Base case } & 2535 & 1.794 \\ \text { Sensitivity case } & 2836 & 1.794 \\ \text { Retrofit/add-on } & & \\ \text { Reference } & 0 & 1.662 \\ \text { Base case } & 1105 & 1.662 \\ & 720 & 1.274 \\ & 0 & 0.886 \\ \text { Sensitivity case } & 1234 & 1.662 \\ & 805 & 1.274\end{array}$





\subsection{CONCLUSIONS}

The economic opportunity for residential cool storage is proportional to the potential savings available by moving all or part of the building's cooling load to a utility's off-peak period. The potential savings is composed of two parts: 1) the magnitude of the cooling load and 2) the savings per kwh available by shifting the load to off-peak hours. The prospects for residential cool storage vary depending on the meteorology and utility rate structure at a particular site. Both the cooling load (for the same building size) and electric rates vary by more than an order of magnitude across the United States. Thus, it is not surprising that the prospects for residential cool storage vary dramatically, depending on site conditions.

The prospects for employing residential cool storage also depend on the perspective of the homeowner and the nature of the TES-augmented system. Costs for TES-augmented systems compete with the full cost of acquiring, operating, and maintaining a conventional air conditioning system in a new construction scenario. In a retrofit scenario, however, the TES-augmented system costs compete with the cost of operating and maintaining a conventional air conditioning system. The lower overall reference cost of cooling for the retrofit scenario makes it more difficult for a replacement TES system to be competitive in the retrofit scenario compared to an add-on TES unit.

In St. Louis, where the number of cooling-degree-days and utility rate structure ranked it at the goth percentile (5th highest out of 50) of locations offering time-of-day rate structures to residential customers, a TES-augmented system in the new construction scenario would be worth $\$ 2700$ to $\$ 3900$ (depending on building size and type) if the TES-augmented system could achieve the same annual COP as the conventional system (1.747 to 1.879 , depending on building size and type). This represents an allowable increase in initial system cost of $\$ 600$ to $\$ 1000$ or approximately 30 to $40 \%$ of the initial cost of a conventional cooling system. Alternatively, a TES-augmented system with the same initial cost as a conventional system would only need to have an annual COP roughly half that of the conventional system for any of the St. Louis residences. These requirements for the new construction scenario apply to the 
entire cooling system, including chill generation, storage, and delivery, and not just to the storage unit itself. System COP is defined as the total chill provided to the residence divided by the total electric energy input to the system on an annual basis.

As expected, residential cool storage prospects in Pittsburgh and Hartford were found to be less attractive. Pittsburgh and Hartford represented the 50th and 10th percentile cities, respectively, in the location rankings developed from the number of cooling-degree-days and electric rate structure. In these two cities, the TES-augmented system in the new construction scenario would be worth $\$ 2100$ to $\$ 2600$ (depending on the site and building type) if it had a COP equal to its reference conventional system (1.582 to 1.834 , depending on site and building type). This represents an allowable increase in initial system cost of $\$ 60$ to $\$ 240$ or approximately $3 \%$ to $10 \%$ of the initial cost of a conventional cooling system. While the rate structure in Pittsburgh would allow a $50 \%$ reduction in annual COP for a TES-augmented system with the same initial cost as the reference conventional system, only a $15 \%$ reduction in efficiency under the same cost conditions was allowable in Hartford, where the benefit per kWh of shifting the electrical load off-peak is lower than for either St. Louis or Pittsburgh.

In general, the prospects for a complete replacement system in a retrofit scenario look poor. For each system evaluated in this scenario, the TES-augmented replacement system would have to be less expensive than its correspondinc conventional unit, while achieving the same annual COP or a higher annual COP for the same cost.

The economic prospects for an add-on storage unit in a retrofit scenario appear much better. A TES add-on unit resulting in a system with the same annual $C O P$ as the reference conventional system (1.621 to 1.743 , depending on building type and size) would be worth $\$ 700$ to $\$ 1100$ in St. Louis (depending on the building type and size). This means that up to $\$ 700$ to $\$ 1100$ could be spent on the storage unit and modifications to the conventional system and still be economically attractive. The annual COP requirement, on the other hand, applies to the entire resulting system, including chill generation, 
storage, and delivery. System COP is still defined as the total chill provided to the residence divided by the total electric energy input to the system on an annual basis. In general, the trends and prospects for the retrofit/addon scenario are similar to that described above for the new construction scenario.

The cost and performance requirements calculated for St. Louis, Hartford, and Pittsburgh were all based on electric rate structures that did not offer any up-front cash incentives or rebates to the residential homeowner. If such incentives or rebates were offered by the utilities, it would directly increase the cost requirement (for a given TES-augmented system COP) by the amount of the cash incentive or rebate.

Sensitivity analyses were conducted for alternative storage sizing, reference (conventiona1) system electric rate structure, and financing rate assumptions. Assuming the chill-generator and storage unit would be sized so that the chill-generator ran continuously (24 hours per day) on the peak cooling day of the year (rather than sizing storage to move all electric demand to the off-peak period) reduced the initial capital cost requirement by $15^{\circ}$ or less for a given level of annual cop. Basing the reference (conventional) system's annual electric bill for cooling on the optional TOD rate (which yielded a higher annual electric bill for cooling than the flat rate) increased the initial capital cost requirements by up to $30 \%$ for a given level of annual COP. Finally, using $5.9 \%$ rather than $10 \%$ as the financing rate increased the initial capital cost requirements by up to $15 \%$ for a given level of annual cop.

It would be difficult to justify the selection of any specific combination of initial capital cost and annual COP as the singular requirement for residential cool storage without considering a target share of the residential market. Meeting the cost and performance requirements of cool storage in Hartford would practically allow targeting of the entire residential market. Meeting the requirements in St. Louis would allow targeting of a small fraction of the total market, but this may still be significant in terms of the number of units and impact on U.S. energy demand. This study has developed initial 
capital cost and annual cop requirements for a broad range of conditions so that interpolation to other conditions could be made.

The current cost and performance requirements identified in this study would be very difficult to achieve. A previous study conducted for the Electric Power Research Institute (Asbury, Giese, and Looney 1986) concluded that a TES-augmented cooling system could probably be installed for a $\$ 2000$ premium above the cost of a conventional cooling system, but noted that very few utility rate structures provide the residential class with a sufficient level of financial incentives for shifting air conditioning demand to off-peak. The cost and performance requirements developed in this study confirm this dilemma. Based on the current characteristics of residential air conditioning equipment and rate structures, the allowable cost premium in St. Louis (the most attractive of the three sites evaluated in this study), was estimated to be only $\$ 1000$.

The cost premium for TES-augmented cooling systems must be lower than $\$ 2000$ and/or greater financial incentives will likely be required from utilities before cool storage becomes economically feasible for the residential homeowner. During the time frame this study was conducted (1987-1988), the availability of TOD rates for the residential class was rapidly increasing. of particular importance, many Southern utilities (where cool storage technologies are expected to have the greatest potential) did not have TOD rates for the residential class at the beginning of the study, but were implementing this type of rate structure as the analytical portion of this study came to a close. The increased availability of TOD rates or other incentives for employing residential cool storage within Southern utilities would significantly change the results of this study. Follow-on efforts should be directed toward tracking the changes in residential rate structures and identifying future-oriented cost and performance requirements when the long-run characteristics of the structure for the residential rate class is more certain. 


\section{REFERENCES}

Air Conditioning and Refrigeration Institute. 1986. Statistical Profile of the Air Conditioning, Refrigeration, and Heating Industry. Air Conditioning and Refrigeration Institute, Arlington, Virginia.

American Society of Heating, Refrigerating, and Air Conditioning Engineers (ASHRAE). 1980. ASHRAE Standard. The American Society of Heating, Refrigerating, and Air-Conditioning Engineers, Inc., Atlanta, Georgia.

Asbury, J. G., R. F. Giese, and Q. Looney. 1986. Market Constraints for Residential Cool Storage Systems. EPRI EM-4722, Electric Power Research Institute, Palo Alto, California.

Brown, D. R., J. A. Dirks, M. K. Drost, G. E. Spanner, and T. A. Williams. 1987. An Assessment Methodology for Thermal Energy Storage Evaluations. PNL-637 2 , Pacific Northwest Laboratory, Richland, Washington.

Commonwealth Edison Co. 1986. Heat Pump Life and Compressor Survival in a Northern Climate. EPRI EM-4660, Electric Power Research Institute, Palo Alto, California.

CSA Energy Consultants. 1986. Electric Rate Book. CSA Energy Consultants, Arlington, Virginia.

Gladstone, J., K. K. Humphreys, and B. K. Lunde. 1987. Mechanical Estimating Guidebook for Building Construction. McGraw-Hill Book Company, New York, New York.

Lawrence Berkeley Laboratory. 1983. Affordable Housing through Energy Conservation. DOE/SF/00098-1, U.S. Department of Energy, Washington, D.C.

Lawrence Berkeley Laboratory. 1985. Overview of the D0E-2 Building Energy Analys is Prograin. LBL-19735, Lawrence Berkeley Laboratory, Berkeley, California.

Mahoney, W. D. 1987. Means Mechanical Cost Data. R.S. Means Company, Inc., Kingston, Massachusetts.

National Oceanic and Atmospheric Administration. 1984. Typical Meteorological Year. TD-9734, National Climatic Center, National Oceanic and Atmospheric Administration, Asheville, North Carolina.

Peters, M. S. and K. D. Timmerhaus. 1980. Plant Design and Economics for Chemical Engineers. McGraw-Hill Book Company, New York, New York. 



\section{DISTRIBUTION}

No. of

Copies

\section{OFFSITE}

U.S. Department of Energy

Attn: K. Kle in

Office of Energy Storage \& Dist.

Forrestal Bidg, CE-32 5E-036

Washington, DC 20585

U.S. Department of Energy

Attn: E. Reimers

Office of Energy Storage \& Dist.

Forrestal B1dg, CE-32 5E-036

Washington, $D C 20585$

10 DOE/Office of Scientific and Technical Information

ANCO Engineers, Inc. Attn: D. M. Bruder 9937 Jefferson Blvd.

Culver City, CA g0232-3591

Argonne National Laboratory

Attn: A. Gorsky

Building 362

9700 S. Cass Avenue

Argonne, IL 60439

Arizona State University

Attn: D. G. Scheatzle

College of Architecture and

Environmental Design

Tempe, AZ 85287

Ayres Ezer Lau Consulting

Engineers

Attn: H. Lau

1180 5. Beverly Drive

Suite 600

Los Angeles, CA 90035
No. of

Copies

Baltimore Aircoil Co. Inc.

Attn: R. E. Cates

PO Box 7322

Baltimore, MD 21227

Baltimore Gas and Electric

Attn: A. J. Killeen

1508 Woodlawn Drive

Baltimore, MD 21207

Brown and Caldwell

Attn: E. Knipe

150 South Arroya Parkway

Pasadena, CA 91109

Calmac Manufacturing Corporation

Attn: C. D. MacCracken

PO Box 710

150 S. Van Brunt St.

Englewood, NJ 07631

Davis Energy Group Inc.

Attn: R. C. Bourne

123 C Street

Davis, CA 95616

District Heating Development Co.

Attn: H. Jaehne

$76 \mathrm{~W}$. Kellogg BTrd.

St, Paul, MN 55102-1161

Dorgan Associates, Inc.

Attn: J. S. Elleson

5610 Medical Circle

Suite 31

Madison, WI 53719

Electric Power Research Institute Attn: D. Geistert

P.0. Box 10412

Palo Alto, CA 94303 
No. of

Copies

Electric Power Research Institute Attn: V. Rab1

P.0. Box 10412

Palo Alto, CA 94303

Electric Power Research Institute Attn: R. Wendland

P.0. Box 10412

Palo Alto, CA 94303

H. C. Fischer

PO Box 445

Maggie Valley, NC 28751

Florida Power and Light Co.

Attn: R. W. Wilkins

P0 Box 029100

9250 West Flagler St.

Miami, FL 33102

Florida Solar Energy Center

Attn: C. J. Cromer

300 State Road 401

Cape Canaveral, FL 32920-4099

Florida Solar Energy Center

Attn: M. K. Khattar

300 State Road 401

Cape Canaveral, FL 32920-4099

George Reeves Associates, Inc.

Attn: G. Reeves

34 McNabb Road

Lk. Hopatcong, NJ 07849

Walter Hauz

4520 Via Vistosa

Santa Barbara, CA 93110

Institute of Gas Technology

Attn: J. O'Sullivan

3424 S. State

Chicago, IL 60612
No. of

Copies

Lennox Industries Inc.

Attn: R. E. Cawley

P0 Box 877

Carrollton, TX 75011-0877

Lennox Industries Inc.

Attn: T. C. Gilles

PO Box 809000

Dallas, TX 75380-9000

Lennox Industries, Inc.

Attn: M. Michel

P0 Box 809000

Dallas, TX 75380-9000

Charles F. Meyer

1141 Cima Linda Lane

Santa Barbara, CA 93108

New York State Energy

Research \& Development

Agency

Attn: G. Walmet

Rockefeller Plaza

Albany, NY 12223

Northern States Power Company

Attn: W. Reder

414 Nicollet Mall

Minneapolis, MN 55401

Oak Ridge National Laboratory

Attn: M. Taylor

Building 9204-1, MS 8045

$Y-12$ Plant, Box 2009

Oak Ridge, TN 37831-8045

Oak Ridge National Laboratory

Attn: J. Tomlinson

Building 9204-1, MS 8045

$Y-12$ Plant, Box 2009

Oak Ridge, TN 37831-8045 
No. of

Copies

Office of Congressman

Sid Morrison

Attn: Kevin Billings,

Legislative Asst.

1330 Longworth Bldg.

Washington, DC 20515

Office of Congressman

Tom Bevill

2302 Rayburn Bidg.

Washington, DC 20515

Pacific Gas and Electric Co.

Attn: J. M. Yokoe

123 Mission Street

Room H-2656

San Francisco, CA 94106

Powell Energy Products, Inc.

Attn: D. P. Hart

PO Box 203

3041 Home Rd.

Powel1, OH 43065-0203

Public Service Electric and Gas Company

Attn: D. A. Pandya

80 Park Plaza

Newark, NJ 07101

Resource Efficiency, Inc.

Attn: Mark Spurr

340 Daly Street

St. Paul, MN 55102

Sacramento Municipal Utility District

Attn: R. H. Kallett

PO Box 15830

6201 S Street, M.S. 73

Sacramento, CA $95852-1830$

Salt River Project

Attn: W. F. James

PO Box 52025

Phoenix, AZ 85072-2025
No. of

Copies

Science Applications International Corporation

Attn: R. H. Sterrett

10260 Campus Point Drive

San Diego, CA 92121

Southern California Edison

Attn: E. Steudtner

PO Box 800

2131 Walnut Grove Avenue

Room 157, G.0.3

Rosemead, CA 91770

South Carolina Electric and

Gas Company

Attn: C. P. Thomas -105

PO Box 764

Columbia, SC 29218

The North Carolina Alternative Energy Corporation

Attn: 0. R. Ferguson

P0 Box 12699

Research Triangle Park, NC 27709

Thermal Energy Storage Inc.

Attn: V. J. ott

PO Box 2033

Del Mar, CA 92014

TUELECTRIC

Attn: K. Schneider

1506 Cormerce St.

Dallas, TX 75201

Turbo Refrigerating Co.

Attn: D. E. Knebel

PO Box 396

1815 Shady 0aks Drive

Denton, TX 76202

UHR Corporation

Attn: C. W. Uhr, Jr.

4562 Eisenhower Ave.

Alexandria, VA 22304 
No. of

Copies

University of Alabama

Attn: E. Brett

School of Mines and Energy

Development

Box 6282

University, AL 35486

University of Massachusetts at Amherst

Attn: D. Breger

Dept. of Mechanical Eng.

Eng. Laboratory Bldg.

Amherst, MA 01003

University of Massachusetts at Amherst

Attn: J. E. Sunderland

Dept. of Mechanical Eng.

Eng. Laboratory Bldg.

Amherst, MA 01003

University of Minnesota

Attn: R. L. Sterling

Underground Space Center

Dept. of Civil and Mineral Eng.

790 Civil and Mineral Eng Bldg

Minneapolis, MN 55455

US Army Corps of Engineers

Construction Engineering

Research Laboratory

Attn: C. W. Sohn

P0 Box 4005

Champaign, IL 61820-1305

US Department of Interior

Attn: Natural Resources

Library

Serials Branch (G/E)

Washington, DC 20240

Wehran Engineering

Attn: R. Miller

PO Box 2006

666 E. Main St.

Middletown, NY 10940
No. of

Copies

Wilke and Associates

Attn: D. Wilke

38 Roosevelt Avenue

Glen Head, NY 11545

FORE IGN

Bengt Hidemark Gosta Danielson Arkitekter SAR

Attn: A. Boysen

Jarntorget 78

S-11 29 Stockholm

Sweden

Deutsche Forschungs- und Versuchsanstalt fuer Luft- und Raumfahrt

Attn: M. Becker

Linder Hoehe

D-5000 Köln 90, West Germany

Deutsche Forschungs- und

Versuchsanstalt fuer

Luft - und Raumfahrt

Attn: R. Tamme

Pfaffenwaldring 38

D-7000 Stuttgart 80

West Germany

Laboratory for Energetics

Attn: B. Quale

Technical University of Denmark

DK-2800 Lyngby

Denmark

Ministry of Trade and Industry

Attn: Pirjo-Liisa Vainio

Energy Department

POHJ. Makasiinikatu 6

SF-00130 Helsinki 13

Finland 
No. of

Copies

Public Works of Canada

Attn: E. L. Morofsky

C456 Sir Charles Tupper Bldg.

Riverside $\mathrm{Dr}$. and Heron Rd.

Ottawa, Ontario

K1A 0M2 Canada

Swedish Council for Building Research

Attn: S-E. Lundin

St. Goransgatan 66

S-112 33 Stockholm

Sweden

Swedish Council for Building Research

Attn: $W$, Raldow

St. Goransgatan 66

S-112 33 Stockholm

Sweden
No. of

Copies

ONSITE

DOE Richland Operations Office

E. C. Norman

38 Pacific Northwest Laboratory

R. C. Adams

J. M. Bates

D. R. Brown (10)

M. K. Drost

C. H. Imhoff

L. D. Kannberg (10)

G. E. Spanner (5)

R. 0. Weijo

T. A. Williams

Technical Report Files (5)

Publishing Coordination 
. 